Prepared in cooperation with the National Park Service and the Texas Commission on Environmental Quality

\title{
Streamflow Gains and Losses and Selected Water-Quality Observations in Five Subreaches of the Rio Grande/Rio Bravo del Norte from near Presidio to Langtry, Texas, Big Bend Area, United States and Mexico, 2006
}
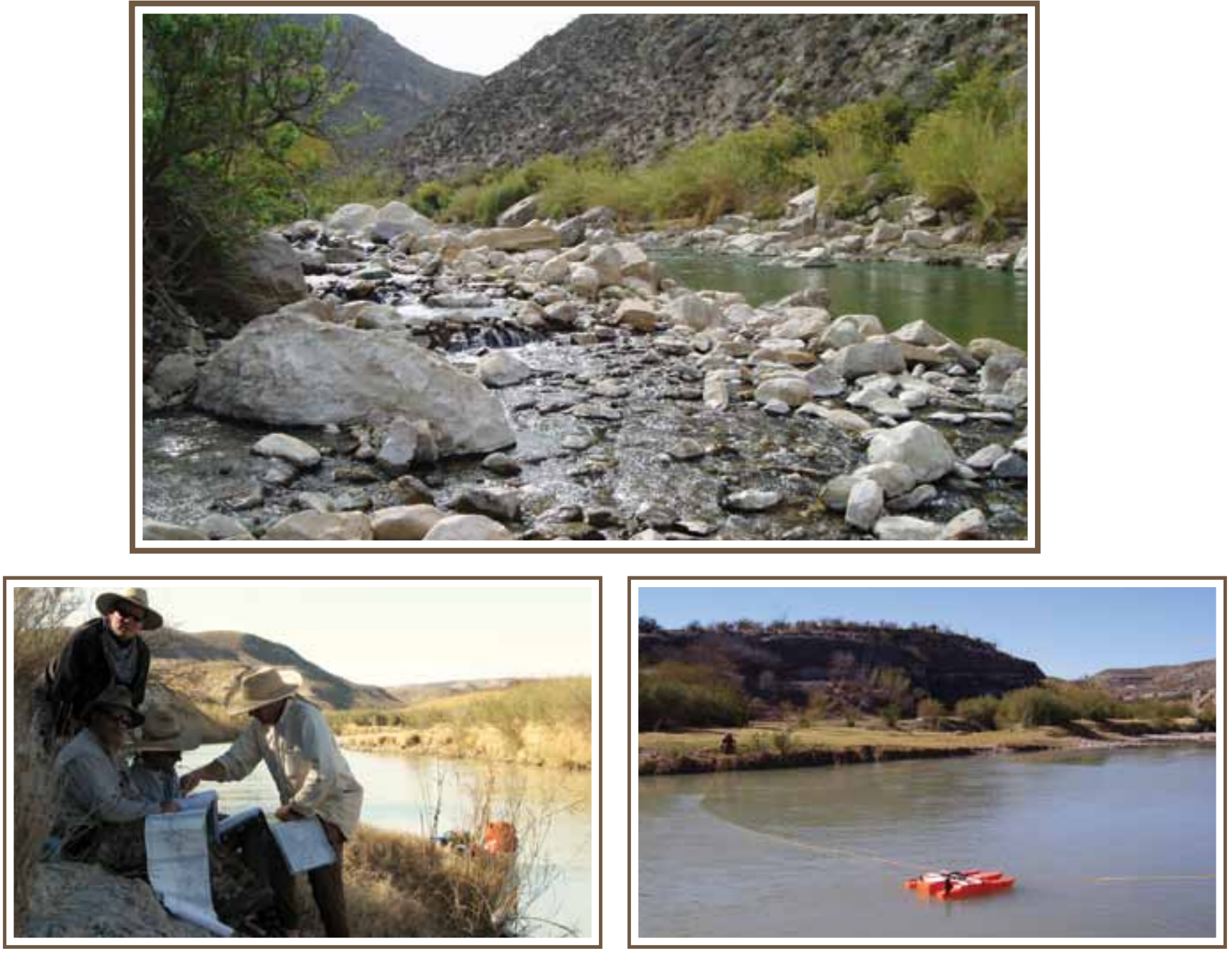

Scientific Investigations Report 2012-5125 


\section{Front cover:}

Top, Rio Grande/Rio Bravo Del Norte in the Lower Canyons (background), with inflow from Hot Springs in Mexico (foreground) near site 22 in Texas, March 2006 (photograph by Michael B. Nyman, U.S. Geological Survey).

Lower left, U.S. Geological Survey, National Parks Service personnel evaluating possible measurement locations on the Rio Grande/Rio Bravo Del Norte, February 2006 (photograph by Cory Horan, Texas Commission on Environmental Quality).

Lower right, U.S. Geological Survey hydrologic technician making a discharge measurement (Acoustic Doppler Current Profiler) on the Rio Grande/Rio Bravo Del Norte, February 2006 (photograph by Christine M. Kolbe, Texas Commission on Environmental Quality).

\section{Back cover:}

Top, Close-up photograph depicting part of a historical map of the Rio Grande/Rio Bravo Del Norte near Big Bend National Park from the 1950s (photograph by Brian L. Petri, U.S. Geological Survey).

Bottom, U.S. Geological Survey hydrologic technician making a discharge measurement (Acoustic Velocity Meter) on the Rio Grande/Rio Bravo Del Norte, February 2006 (photograph by Mark A. Warzecha, U.S. Geological Survey). 


\section{Streamflow Gains and Losses and Selected Water-Quality Observations in Five Subreaches of the Rio Grande/Rio Bravo del Norte from near Presidio to Langtry, Texas, Big Bend Area, United States and Mexico, 2006}

By Timothy H. Raines, Michael J. Turco, Patrick J. Connor, and Jeffery B. Bennett

Prepared in cooperation with the National Park Service and the Texas

Commission on Environmental Quality

Scientific Investigations Report 2012-5125 


\title{
U.S. Department of the Interior \\ KEN SALAZAR, Secretary \\ U.S. Geological Survey \\ Marcia K. McNutt, Director
}

\section{U.S. Geological Survey, Reston, Virginia: 2012}

\author{
This and other USGS information products are available at http://store.usgs.gov/ \\ U.S. Geological Survey \\ Box 25286, Denver Federal Center \\ Denver, CO 80225 \\ To learn about the USGS and its information products visit http://www.usgs.gov/ \\ 1-888-ASK-USGS
}

\footnotetext{
Any use of trade, product, or firm names is for descriptive purposes only and does not imply endorsement by the U.S. Government.

Although this report is in the public domain, permission must be secured from the individual copyright owners to reproduce any copyrighted materials contained within this report.
}

Suggested citation:

Raines, T.H., Turco, M.J., Connor, P.J., and Bennett, J.B., 2012, Streamflow gains and losses and selected waterquality observations in five subreaches of the Rio Grande/Rio Bravo del Norte from near Presidio to Langtry, Texas, Big Bend area, United States and Mexico, 2006: U.S. Geological Survey Scientific Investigations Report 2012-5125, 30 p. 


\section{Acknowledgments}

The authors acknowledge the many property owners who provided access to the Rio Grande and the technical support provided by Adam Zerrenner (U.S. Fish and Wildlife Service, Ecological Services Field Office, Austin, Texas) through the U.S. Geological Survey/National

Park Service Water Quality Partnership, as well as the National Park Service river rangers who facilitated the collection of data used in this report. 



\section{Contents}

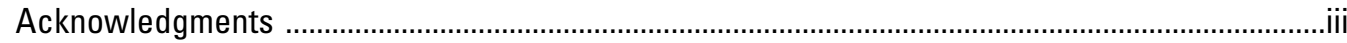

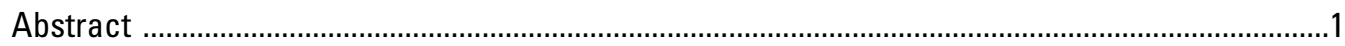

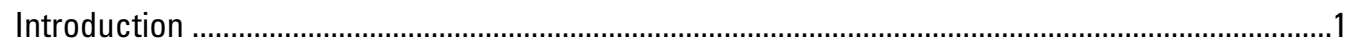

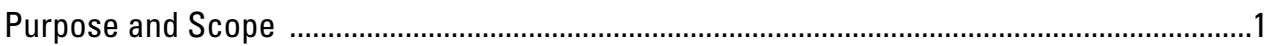

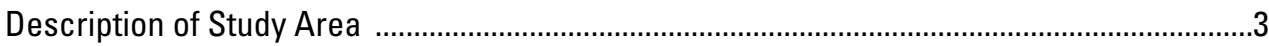

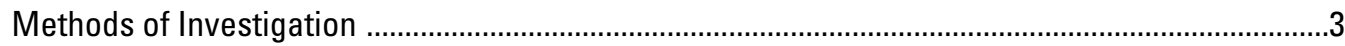

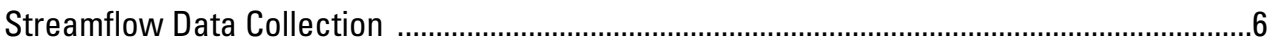

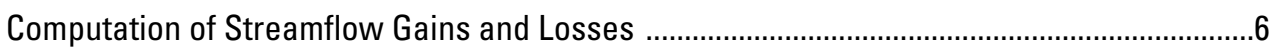

Water-Quality Data Collection and Analysis ...........................................................................

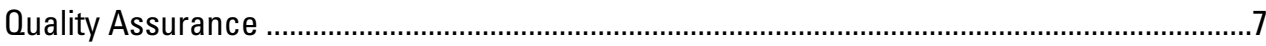

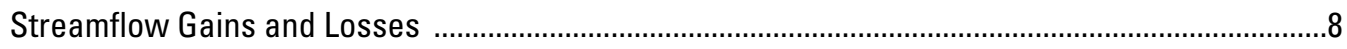

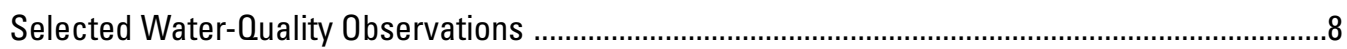

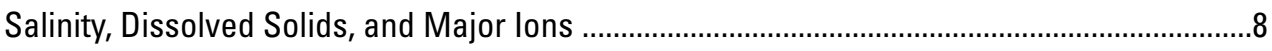

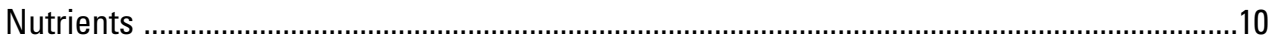

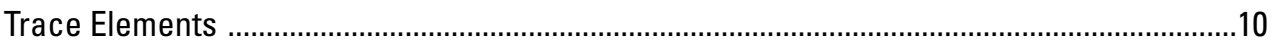

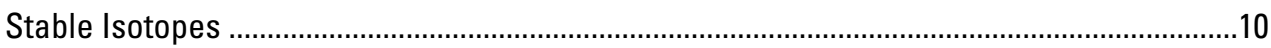

Summary ……

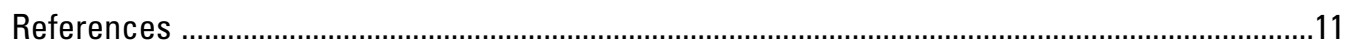

Appendix 1. Oxygen and nitrogen isotope data in water-quality samples from the main-stem Rio Grande, Big Bend area, United States and Mexico,

February 5-June 29, 2006

\section{Figures}

1. Map showing Rio Grande/Rio Bravo del Norte (Rio Grande) in the Big Bend area, United States and Mexico, 2006

2. Map showing location of data-collection sites and subreaches $A-E$ along the Rio Grande, Big Bend area, United States and Mexico, 2006

3. Map showing major and minor aquifers in the Big Bend area, United States and Mexico

4. Graph showing instantaneous discharge for data-collection sites on the Rio Grande in subreaches A-E, Big Bend area, United States and Mexico, FebruaryJune 2006

\section{Tables}

1. Sites at which measurements for streamflow gain and loss computation were made on the Rio Grande and one tributary, from near Presidio to near Langtry, Texas, Big Bend area, United States and Mexico, February-June 2006

2. Criteria and screening levels used to assess surface-water quality in Texas

3. Quality-assurance data for physical properties, major ions, nutrients, and trace elements measured in samples collected from the main-stem Rio Grande, Big Bend area, United States and Mexico, 2006 
4. Streamflow gains and losses computed for sites on the Rio Grande, Big Bend area, United States and Mexico, 2006

5. Selected physical properties and water-quality constituents, including salinity, dissolved solids, and major ions, measured in samples from the main-stem Rio Grande, Big Bend area, United States and Mexico, February 5-June 29, 2006

6. Nutrient data in water-quality samples from the main-stem Rio Grande, Big Bend area, United States and Mexico, February 5-June 29, 2006

7. Trace-element data in water-quality samples from the main-stem Rio Grande, Big Bend area, United States and Mexico, February 5-June 29, 2006

\section{Conversion Factors, Datum, and Water-Quality Units}

\section{Inch/Pound to SI}

\begin{tabular}{lcl}
\hline \multicolumn{1}{c}{ Multiply } & By & \multicolumn{1}{c}{ To obtain } \\
\hline foot $(\mathrm{ft})$ & Length & \\
mile $(\mathrm{mi})$ & 0.3048 & meter $(\mathrm{m})$ \\
& 1.609 & kilometer $(\mathrm{km})$ \\
\hline acre & Area & \\
\hline & 0.4047 & hectare $(\mathrm{ha})$ \\
\hline cubic foot per second $\left(\mathrm{ft}^{3} / \mathrm{s}\right)$ & Flow Rate & \\
\hline
\end{tabular}

Temperature in degrees Celsius $\left({ }^{\circ} \mathrm{C}\right)$ may be converted to degrees Fahrenheit $\left({ }^{\circ} \mathrm{F}\right)$ as follows:

$$
{ }^{\circ} \mathrm{F}=\left(1.8 x^{\circ} \mathrm{C}\right)+32
$$

\section{Datum}

Horizontal coordinate information is referenced to the North American Datum of 1983 (NAD 83).

\section{Water-Quality Units}

Specific conductance is given in microsiemens per centimeter at 25 degrees Celsius $(\mu \mathrm{S} / \mathrm{cm}$ at $\left.25^{\circ} \mathrm{C}\right)$.

Concentrations of chemical constituents in water are given in either milligrams per liter $(\mathrm{mg} / \mathrm{L})$ or micrograms per liter $(\mu \mathrm{g} / \mathrm{L})$. 


\title{
Streamflow Gains and Losses and Selected Water-Quality Observations in Five Subreaches of the Rio Grande/Rio Bravo del Norte from near Presidio to Langtry, Texas, Big Bend Area, United States and Mexico, 2006
}

\author{
By Timothy H. Raines, ${ }^{1}$ Michael J. Turco, ${ }^{1}$ Patrick J. Connor, ${ }^{2}$ and Jeffery B. Bennett ${ }^{3}$
}

\begin{abstract}
Few historical streamflow and water-quality data are available to characterize the segment of the Rio Grande/Rio Bravo del Norte (hereinafter Rio Grande) extending from near Presidio to near Langtry, Texas. The U.S. Geological Survey, in cooperation with the National Park Service and the Texas Commission on Environmental Quality, collected waterquality and streamflow data from the Rio Grande from near Presidio to near Langtry, Texas, to characterize the streamflow gain and loss and selected constituent concentrations in a 336.3-mile reach of the Rio Grande from near Presidio to near Langtry, Texas. Streamflow was measured at 38 sites and water-quality samples were collected at 20 sites along the Rio Grande in February, March, and June 2006. Streamflow gains and losses over the course of the stream were measured indirectly by computing the differences in measured streamflow between sites along the stream. Water-quality data were collected and analyzed for salinity, dissolved solids, major ions, nutrients, trace elements, and stable isotopes. Selected properties and constituents were compared to available Texas Commission on Environmental Quality general use protection criteria or screening levels. Summary statistics of selected water-quality data were computed for each of the five designated subreaches. Streamflow gain and loss and water-quality constituent concentration were compared for each subreach, rather than the entire segment because of the temporal variation in sample collection caused by controlled releases upstream. Subreach A was determined to be a losing reach, and subreaches B, C, D, and E were determined to be gaining reaches. Compared to concentrations measured in upstream subreaches, downstream subreaches exhibited evidence of dilution of selected constituent concentrations. Subreaches A
\end{abstract}

\footnotetext{
${ }^{1}$ U.S. Geological Survey.

${ }^{2}$ U.S. Fish and Wildlife Service.

${ }^{3}$ National Park Service.
}

and B had measured total dissolved solids, chloride, and sulfate exceeding the Texas Commission on Environmental Quality general use protection criteria. Subreaches C, D, and $\mathrm{E}$ did not exceed the general use protection criteria for any constituent concentration criteria, but dissolved oxygen concentrations did not meet the general use criteria in these subreaches.

\section{Introduction}

Few historical streamflow and water-quality data are available to characterize the segment of the Rio Grande/Rio Bravo del Norte (hereinafter Rio Grande) extending from near Presidio to near Langtry, Tex. The Rio Grande forms the boundary between Texas in the United States and the States of Chihuahua and Coahuila in Mexico. About 3.5 million acres of protected lands exist on both sides of the Rio Grande, and more than 250 miles (mi) of the river are under some form of conservation protection between Presidio and Langtry. Parks and protected areas along this part of the Rio Grande include the Big Bend Ranch State Park, Big Bend National Park, Black Gap State Wildlife Management Area, and Rio Grande Wild and Scenic River in the United States, and the Áreas de Protección de Flora y Fauna Cañón de Santa Elena, Ocampo, and Maderas del Carmen in Mexico (fig. 1). All of these parks and protected areas are downstream from the confluence of the Rio Conchos and the Rio Grande. In 2006, the U.S. Geological Survey (USGS), in cooperation with the National Park Service and the Texas Commission on Environmental Quality (TCEQ), did a study to characterize streamflow gain and loss and the quality of water in five subreaches of the Rio Grande from near Presidio to near Langtry.

\section{Purpose and Scope}

The purpose of this report is to provide an initial characterization of streamflow gain and loss and water quality in five 


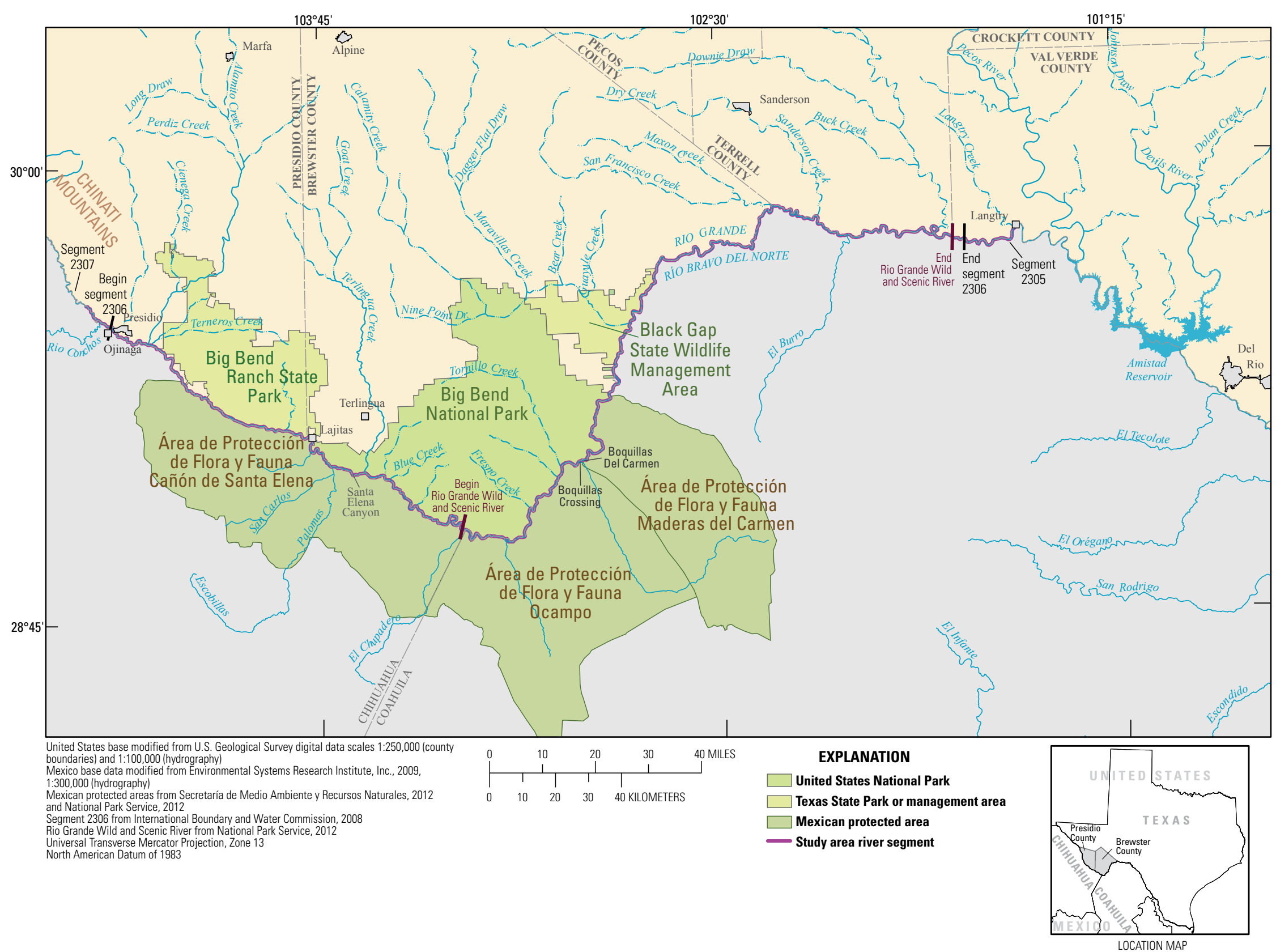

Figure 1. Rio Grande/Rio Bravo del Norte (Rio Grande) in the Big Bend area, United States and Mexico, 2006. 
subreaches of the Rio Grande extending from near Presidio to near Langtry. Streamflow gains and losses and water-quality properties were measured in the five subreaches during three synoptic surveys done between February and June 2006 and at one site upstream from the five subreaches during June 2006. Water-quality data were compared to available Texas Surface Water Quality Standards or to screening levels in the absence of State standards.

\section{Description of Study Area}

Streamflow and water-quality data were obtained from a 336.3-mi reach of the Rio Grande from near Presidio to near Langtry along the U.S.-Mexico border (fig. 1). The study reach includes parts of Presidio, Brewster, Terrell, and Val Verde Counties in Texas. Segment 2306 represents most of the Rio Grande in the study area; the segment begins about 1 mi downstream from the confluence of the Rio Grande and Rio Conchos near Presidio and ends about 313 mi downstream where the river is first affected by backwater from Amistad Reservoir, near the Terrell and Val Verde County line (International Boundary and Water Commission, 2005) (fig. 2). Designated uses in segment 2306 include aquatic life, contact recreation, general use, fish consumption, and public water supply. Listed concerns for this segment include excessive algal growth (caused by elevated nutrient concentrations) and elevated total dissolved-solids and sulfate concentrations (Texas Commission on Environmental Quality, 2002).

The Rio Grande hydrology is noted for long periods (months) of base flow punctuated by flashy high flows (Schmandt and others, 2000). The greatest precipitation occurs during July, August, and September during the annual North American monsoon (National Climatic Data Center, 2011). North American monsoon-associated precipitation is noted for broad variation in time (interseasonal to interannual) and space. Part of this variability is attributed to surges of moisture from the Gulf of California and to changes in latitudinal position of the subtropical ridge over Mexico and the Southwestern United States (Adams and Comrie, 1997). During 1968-2005, the highest monthly mean discharge (as measured in the Rio Grande downstream from the Rio Conchos near Presidio) was measured in September; the second and third highest monthly mean discharges were in October and August, respectively (International Boundary and Water Commission, 2003).

Rio Grande tributaries (streams and arroyos) in the study area are typically intermittent dry washes. The duration of flow (typically, hours to days) in these streams is tied to the intensity and duration of precipitation and runoff. Some small streams in the Big Bend area receive flow from springs and seeps that are typically perennial but generally do not add sufficiently to the Rio Grande to discern their contribution to flow. Much of the flow in the Rio Grande near Presidio consists of inflow from the Rio Conchos (Patrick, 2003).
The Rio Grande is hydraulically connected to alluvial deposits in the stream channel. The alluvium is composed of silty sand, clay, and gravel (Berry and Williams, 2008). In addition to agricultural uses near Presidio, some of the flow in the Rio Grande is also likely lost by seepage and recharge to the alluvium (U.S. Army Corps of Engineers, 2008). Irrigated fields near Presidio are in direct connection to the alluvium, which may be a source of return flow to the Rio Grande (Reeves and Small, 1973). Groundwater recharge occurs in alluvial fans, along faults, and along stream channels; groundwater discharges from springs to the Rio Grande are common in some parts of the Rio Grande between Presidio and Langtry (Dr. Shirley Wade, Texas Water Development Board, written commun., 2006).

The Edwards-Trinity aquifer is the major aquifer in the study area. Minor aquifers in the study area include the Igneous, Marathon, and West Texas Bolsons (Ashworth and Hopkins, 1995) (fig. 3). Faulting occurs throughout the study area and can alter or impede local groundwater flow paths (Baker and Buszka, 1993; Bartolino and Cole, 2002; Gray and Page, 2008).

\section{Methods of Investigation}

Streamflow measurements were made and water-quality samples collected in five subreaches of the Rio Grande to measure streamflow gains and losses during February-June 2006 (an additional streamflow measurement and water-quality sampling site was upstream from the most upstream subreach). At 20 of the 38 streamflow-measurement sites, water-quality samples were collected at the time streamflow measurements were made (table 1 at end of report). Streamflow gain and loss and water-quality constituent concentrations were compared for each subreach. Subreaches were labeled A through E in consecutive downstream order. Subreach A is the most upstream reach in the study area; beginning near Presidio, it spans $48.1 \mathrm{mi}$. Subreach B is the longest reach in the study area, spanning $79.7 \mathrm{mi}$ of the Rio Grande. Subreach C is the shortest reach in the study area and spans $23.7 \mathrm{mi}$ of the river. Subreach D spans $60.7 \mathrm{mi}$ of the Rio Grande, and Subreach E spans $55.0 \mathrm{mi}$ of the Rio Grande, ending near Langtry (fig. 2; table 1).

At each water-quality sampling site, selected physical properties (dissolved oxygen, $\mathrm{pH}$, specific conductance, water temperature, and alkalinity) and water-quality constituents (salinity, total dissolved solids, major ions, nutrients, and trace elements) were measured. Ratios of the stable isotopes of oxygen (oxygen-18 to oxygen-16) and nitrogen (nitrogen-15 to nitrogen-14) also were measured. Water-quality data were compared (table 2 at end of report) to available Texas Surface Water Quality Standards (Texas Commission on Environmental Quality, 2010) or to screening levels (Lambert and others, 2008, table 3 at end of report) for selected water-quality constituents. 


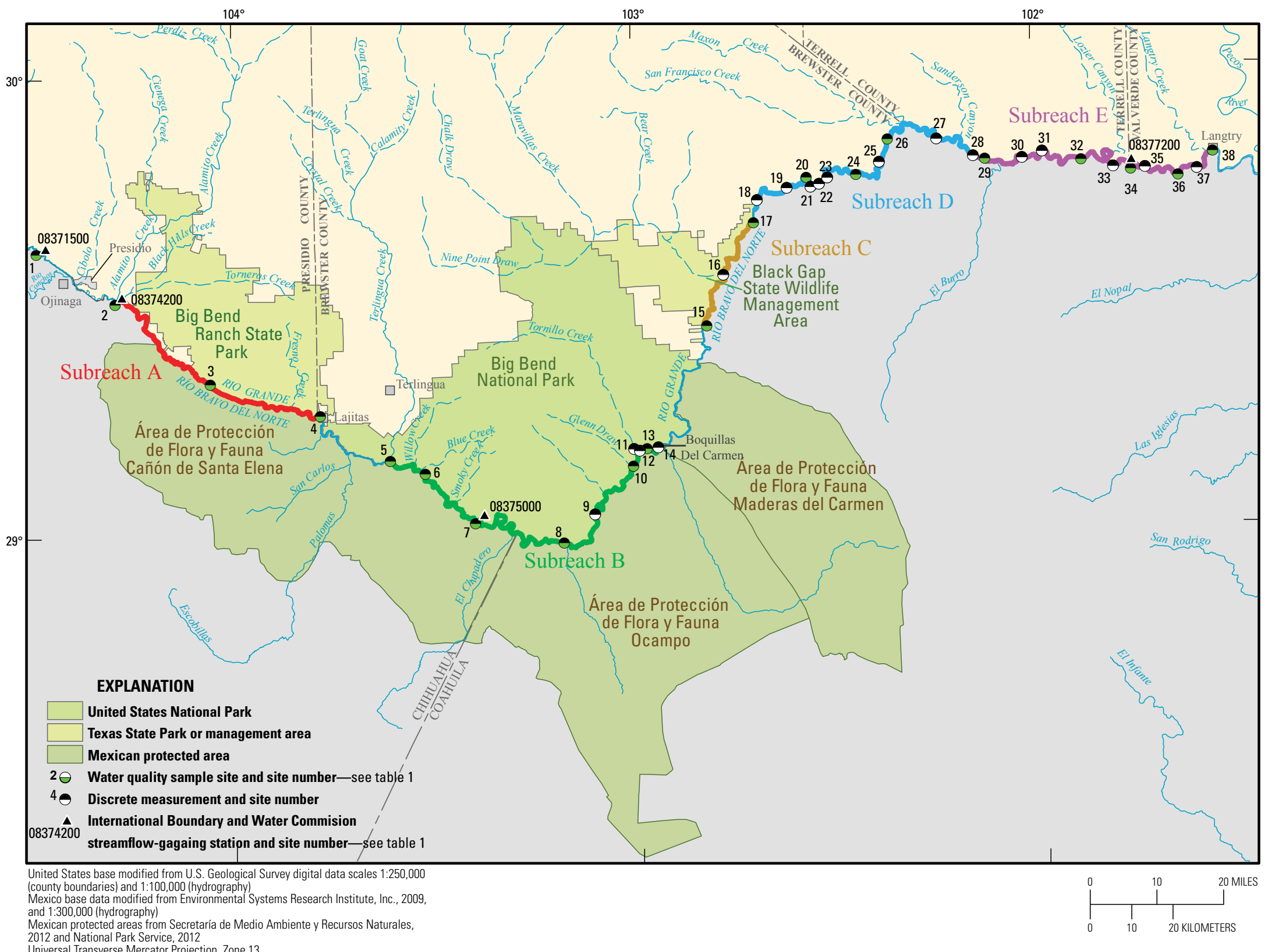

Figure 2. Location of data-collection sites and subreaches A-E along the Rio Grande, Big Bend area, United States and Mexico, 2006. 


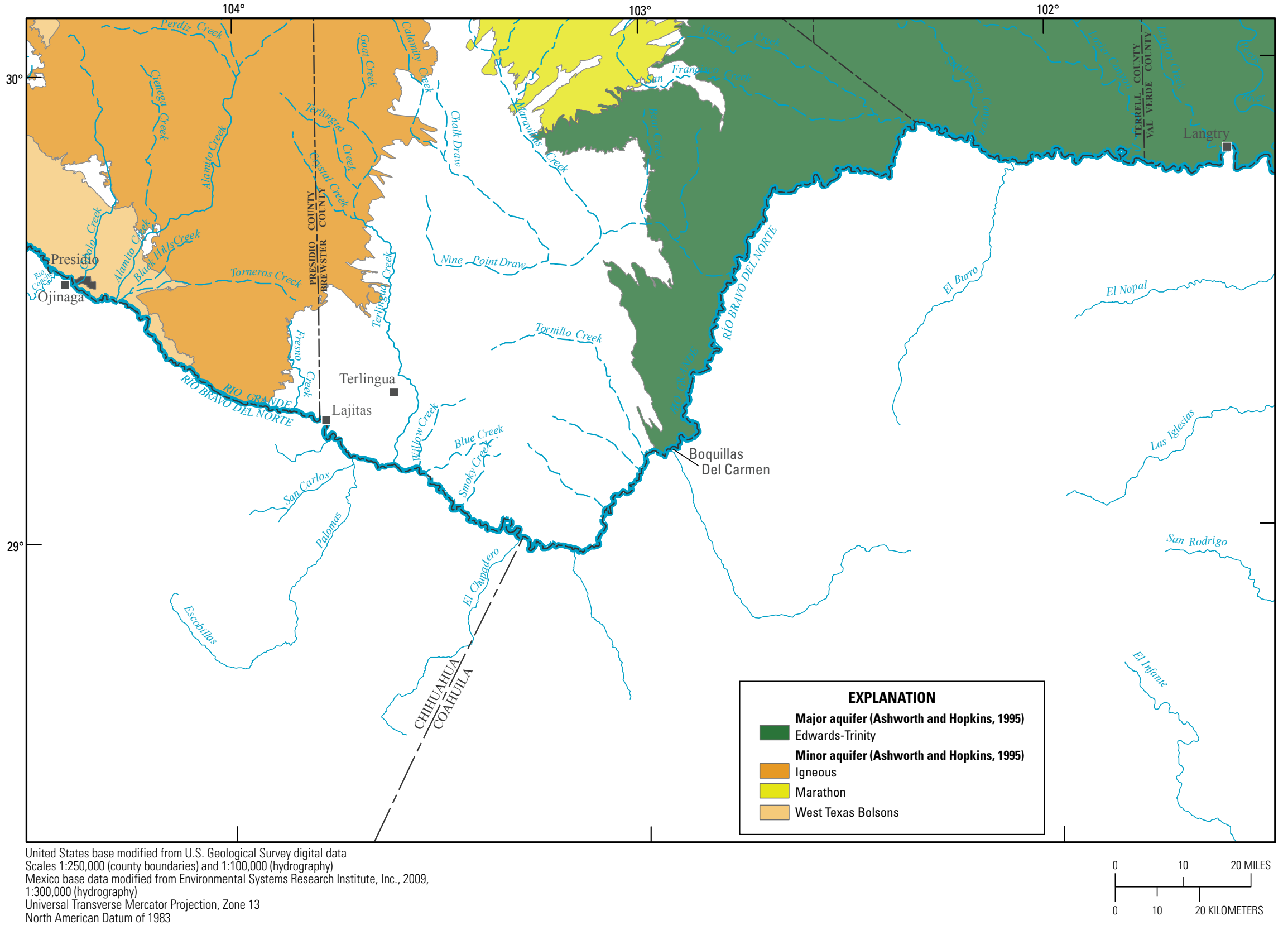

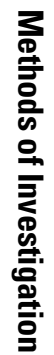

Figure 3. Major and minor aquifers in the Big Bend area, United States and Mexico. 


\section{Streamflow Data Collection}

Streamflow data were collected at 37 sites on the Rio Grande and 1 tributary site adjacent to the Rio Grande during February 5-June 29, 2006. At three sites (sites 2, 7, and 34) streamflow was obtained from the nearest International Boundary and Water Commission streamflow-gaging station (fig. 2; table 1). At all other sites, discrete measurements of streamflow were made in each subreach using USGS methods (Rantz and others, 1982; Turnipseed and Sauer, 2010).

Streams were waded and velocity measurements were made using rod-mounted acoustic meters (Turnipseed and Sauer, 2010) where conditions allowed (water depths generally less than 3 feet). In all other instances, boat-mounted acoustic Doppler current profilers were used to measure streamflow (Oberg and others, 2005). USGS protocols describing the operation and maintenance of streamflow measuring equipment were followed (Turnipseed and Sauer, 2010).

\section{Computation of Streamflow Gains and Losses}

Streamflow gains and losses over the length of a subreach were measured indirectly by computing the differences in streamflow between consecutive sites in each subreach and for the overall length of the subreach based on an approach described by Turco and others (2007). Sources of gains or losses between sites, in addition to groundwater inflow or outflow through the streambed, might include tributary inflow, diversions, return flows, and evaporation. Using these factors, streamflow gain or loss in the reach is computed as

$$
G=Q_{d}-Q_{u}-I+D-R+E+E T,
$$

where

\begin{tabular}{|c|c|}
\hline$G$ & $\begin{array}{l}\text { ow gain or loss (groundwater } \\
\text { or outflow), in cubic feet per }\end{array}$ \\
\hline$Q_{d}$ & $\begin{array}{l}\text { d streamflow at the downstream } \\
\text { cubic feet per second; }\end{array}$ \\
\hline$Q_{u}$ & $\begin{array}{l}\text { is measured streamflow at the upstream site, } \\
\text { in cubic feet per second; }\end{array}$ \\
\hline$I$ & $\begin{array}{l}\text { is measured inflows from tributaries, in cubic } \\
\text { feet per second; }\end{array}$ \\
\hline$D$ & $\begin{array}{l}\text { is measured outflows, in cubic feet per } \\
\text { second; }\end{array}$ \\
\hline$D$ & $\begin{array}{l}\text { is return flows to the reach, in cubic feet per } \\
\text { second; }\end{array}$ \\
\hline & is evaporation, in cubic feet per second; and \\
\hline
\end{tabular}

Tributaries were checked for any inflows at their confluence with the Rio Grande at the time of Rio Grande measurements. The Rio Conchos is upstream from the subreaches where gains and losses were calculated. In subreaches A-E, all tributaries that were observed appeared to be dry streambeds that did not appear to contribute flow to the Rio Grande except for one site where less than 1 cubic foot per second $\left(\mathrm{ft}^{3} / \mathrm{s}\right)$ was measured (site 12). Most of the irrigation withdrawals and return flows occur upstream from subreach A; those affecting subreach A would likely vary considerably day to day and would be difficult to quantify during the study period and were therefore not accounted for in the gain-loss calculations. No wastewater-treatment plants are known to discharge to the Rio Grande in subreaches A through E. There may have been an unknown amount of subsurface flow in the alluvium of the dry streambeds. For this study, upstream $\left(Q_{u}\right)$ and downstream $\left(Q_{d}\right)$ measured streamflow were the only components used in the calculation of gain and loss over a reach, defined as the main-stem length between adjacent sites. The magnitude of error associated with the exclusions of other gain and loss components was believed to be minor when compared to potential errors associated with the streamflow measurements.

Individual streamflow measurement error must be considered when evaluating the streamflow gain and loss determined solely by individual discharge measurements. Measurement error was based on a qualitative rating (excellent, good, fair, and poor) of the streamflow measurement by the hydrographer (Sauer and Meyer, 1992). The rating is based on factors such as cross-section condition, velocity homogeneity, streambed conditions, and other factors that affect the accuracy of the measurement. Measurements rated "excellent" are believed to be within 2 percent of the actual flow, "good" measurements are believed to be within 5 percent, "fair" measurements are believed to be within 8 percent, and "poor" measurements are believed to differ from the actual flow by greater than 8 percent. The potential errors associated with each pair of streamflow measurements within a reach were summed to obtain the composite potential error for comparison with the computed gain or loss. Differences between streamflow measured at sites in each subreach were computed and compared to the composite potential error associated with each discharge measurement. For this report, apparent gains (or losses) are described when the difference between streamflow at the upstream and downstream measuring sites that define the reach was greater than (or less than) the composite potential error associated with the streamflow measurements. For example, two fair measurements of 100 and $120 \mathrm{ft}^{3} / \mathrm{s}$ would have a composite potential error of $100 * 0.08+120 * 0.08=$ $17.6 \mathrm{ft}^{3} / \mathrm{s}$, which is less than the difference in measurements, $120-100=20 \mathrm{ft}^{3} / \mathrm{s}$.

\section{Water-Quality Data Collection and Analysis}

Water-quality data were collected from selected sites in each subreach in conjunction with streamflow measurements (table 1). Water-quality samples were collected, processed, and 
preserved using standard USGS protocols as described in the "National Field Manual for the Collection of Water-Quality Data" (U.S. Geological Survey, variously dated). Selected physical properties and constituents (including dissolved oxygen, $\mathrm{pH}$, salinity, specific conductance, water temperature, and alkalinity) were measured in the field in accordance with standard USGS methods (U.S. Geological Survey, variously dated). Salinity, in parts per thousand, was estimated from a 30-point rating table in Wagner and others (2000) using specific conductance values measured at each site. Major-ion and trace-element concentrations were measured using filtered samples; these samples were filtered through a 0.45 -micrometer membrane filter and acidified with ultrapure nitric acid to pH less than 2 standard units (Garbarino and Taylor, 1996). The concentrations of total dissolved solids, major ions, nutrients, and trace elements in the water samples were determined by the USGS National Water Quality Laboratory (NWQL) in Denver, Colo., using approved methods (Fishman and Friedman, 1989; Patton and Truitt, 1992, 2000; Fishman, 1993; Garbarino and Struzeski, 1998; Garbarino, 1999; Garbarino and others, 2006). Stable environmental isotopes are measured as the ratio of the two most abundant isotopes of a given element (Clark and Fritz, 1997). The ratios of naturally occurring, stable isotopes of oxygen and nitrogen of water were measured by the USGS Stable Isotope Laboratory in Reston, Va., using approved methods (Epstein and Mayeda, 1953; Coplen and others, 1991). Results for stable isotope analysis of the ratio of oxygen-18 to oxygen-16 and nitrogen-15 to nitrogen-14 are reported as delta oxygen-18 $\left(\delta^{18} \mathrm{O}\right)$ and delta nitrogen-15 $\left(\delta^{15} \mathrm{~N}\right)$, respectively, which represent the relative difference in parts per thousand (per mil) between the sample isotope ratio and the isotope ratio of a known standard (Kendall and McDonnell, 1998).

As explained by Oden and others $(2011$, p. 9) "the analytical quantification procedure used by the NWQL for reporting results is based on the long-term method detection level (LT-MDL) and laboratory reporting level (LRL). The LT-MDL concentrations are defined as a censoring limit for most analytical methods at the NWQL, and its purpose is to limit the false positive rate to less than or equal to 1 percent. An LT-MDL is a modification of the USEPA 40 Code of Federal Regulations Part 136 definition of the method detection limit (MDL). The LRL is defined as twice the LT-MDL and is established to limit the occurrence of false negative detections to less than or equal to 1 percent (Childress and others, 1999). A constituent concentration is considered estimated by the laboratory when results are greater than the LT-MDL and less than the LRL; that is, a detection is considered likely, but quantification is considered questionable. The remark code of "E" (estimated) is assigned by the laboratory for these results."

The Texas Surface Water Quality Standards (TSWQS), Title 30, Chapter 307 of the Texas Administrative Code, was written by the TCEQ with the authority of Section 303(c) of the Clean Water Act and Section 26.023 of the Texas Administrative Code (Texas Commission on Environmental Quality,
2010). The standards established specific water-quality goals for specific stream segments, lakes, and reservoirs throughout Texas. The TSWQS include specific numerical criteria for 30 toxic contaminants, maximum allowable in-stream concentrations for specific constituents, and criteria needed to protect aquatic life. Water-quality data for selected constituents were compared to applicable TSWQS criteria (Texas Commission on Environmental Quality, 2010) or to screening levels (Lambert and others, 2008, table 3) in the absence of State standards (table 2).

\section{Quality Assurance}

Quality-assurance and quality-control information was collected as part of this study to provide a measure of uncertainty in the streamflow and water-quality measurements. Replicate streamflow measurements were made at 15 selected sites on the same day representing 16 pairs of measurements; the differences between replicate streamflow measurements computed as the relative percent difference were less than 5 percent (table 1). For sites where two streamflow measurements were made on the same day, the average of the replicate measurements was used for gain-loss calculations. A waterquality field-blank sample was collected in February 2006 at International Boundary and Water Commission station 08377200 Rio Grande at Foster Ranch near Langtry, Tex. (site 34); a sequential-replicate water-quality sample also was collected in February 2006 at USGS station 290855103002800 Rio Grande at La Clocha Campground, Big Bend National Park, Tex. (site 10). Quality-control water samples were collected as described in the "National Field Manual for the Collection of Water-Quality Data" (U.S. Geological Survey, variously dated) and analyzed by the same laboratory following the same methods used to analyze the environmental samples. Quality-assurance data for water-quality constituents are listed in table 3, including the results from the sequentialreplicate water-quality samples.

No target analytes were detected in the field blank sample. The sequential-replicate samples were analyzed to determine the variability of the results for target analytes. The relative percent difference (RPD) was determined for each pair of replicate analyses as a measure of variability. The RPD for each constituent was computed using the equation

$$
R P D=\left|C_{1}-C_{2}\right| /\left(\left(C_{1}+C_{2}\right) / 2\right) \times 100,
$$

where

$$
\begin{gathered}
C_{1} \quad \begin{array}{l}
\text { is the concentration from the first sample in } \\
\text { the replicate pair; and }
\end{array} \\
C_{2} \quad \text { is the concentration from the second sample } \\
\text { in the replicate pair. }
\end{gathered}
$$

The RPDs for water-quality constituents were generally 10 percent or smaller, indicating good analytical precision (table 3). 


\section{Streamflow Gains and Losses}

During the study, discharge in the Rio Grande ranged from $4.06 \mathrm{ft}^{3} / \mathrm{s}$ at site 1 upstream from where the Rio Conchos flows into the Rio Grande (upstream from subreach A) to $450 \mathrm{ft}^{3} / \mathrm{s}$ at site 38 , the most downstream site of the study (table 1). Using measurements made in February, March, and June 2006, streamflow gains and losses were computed in subreaches A-E. Tributary inflow from one site (site 12 in subreach B) of $0.64 \mathrm{ft}^{3} / \mathrm{s}$ was also measured during February 2006.

To analyze streamflow gains and losses, differences between streamflow measured at sites on the main-stem Rio Grande in subreaches A-E were computed for consecutive sites and for the most upstream and downstream sites in a given subreach and then compared to the potential error associated with each discharge measurement (table 4 at end of report). Only 7 of the 31 differences in streamflow between consecutive upstream and downstream sites were greater than the sum of the measurement error associated with each measurement, indicating an apparent gain or loss between the individual sites within each subreach.

Streamflow measurements for the sites on the Rio Grande within each subreach are plotted against location as represented in river miles downstream from site 1 (fig. 4). Subreach A is the most upstream reach in the study area, spanning $48.1 \mathrm{mi}$ of the Rio Grande between sites 2 and 4 (fig. 2; table 1). Streamflow was measured in subreach A during June 20-29, 2006, and decreased from $41.2 \mathrm{ft}^{3} / \mathrm{s}$ at the upstream end to $15.0 \mathrm{ft}^{3} / \mathrm{s}$ at the downstream end of the subreach. An apparent loss in streamflow in subreach A was quantified (table 4). Streamflow at the most downstream site in subreach B (173 $\mathrm{ft}^{3} / \mathrm{s}$ at site 14) was much larger compared to streamflow at the most upstream site in subreach $\mathrm{C}\left(55.4 \mathrm{ft}^{3} / \mathrm{s}\right.$ at site 15$)$. Site 17 was the most downstream site in subreach $C$ during June when $92.6 \mathrm{ft}^{3} / \mathrm{s}$ was measured and also the most upstream site in subreach D during March when $162 \mathrm{ft}^{3} / \mathrm{s}$ was measured. The large apparent loss shown in figure 4 between subreaches B and $C$ and the large apparent gain between subreaches $C$ and $\mathrm{D}$ results from seasonal differences in base flow; there was less flow in Rio Grande in the study area in June compared to February and March. Streamflow measurements were made during February or March in subreaches B, D and E, whereas they were made during June in subreaches $A$ and $C$.

Subreach B, the longest reach on the Rio Grande within the study area, spans $79.7 \mathrm{mi}$ of the Rio Grande between sites 5 and site 14 (fig. 2; table 1). Streamflow in subreach B ranged from 109 to $173 \mathrm{ft}^{3} / \mathrm{s}$ during February 6-10, 2006 (table 4). For consecutive streamflow measurements made in this reach, no change in streamflow was determined where the difference in streamflow exceeded the measurement error. Between the most upstream to most downstream sites in subreach B, an apparent gain in streamflow was quantified.

Subreach $\mathrm{C}$ is the shortest reach on the Rio Grande within the study area, spanning $23.7 \mathrm{mi}$ between sites 15 and 17 (fig. 2; table 1). Streamflow ranged from 49.0 to $92.6 \mathrm{fo}^{3} / \mathrm{s}$ on June 22, 2006; an apparent gain in streamflow was quantified for this reach (table 4).

Subreach D spans 60.7 mi between sites 17 and 28 . Streamflow was measured during March 13-19, 2006. Streamflow increased from $162 \mathrm{ft}^{3} / \mathrm{s}$ at site 17 to $278 \mathrm{ft}^{3} / \mathrm{s}$ at site 26 (measurements from sites 27 and 28 were not used because they were affected by releases from reservoirs in Mexico thus affecting the amount of inflow from the Rio Conchos). For most consecutive streamflow measurements in subreach $\mathrm{D}$, no change in streamflow was determined where the difference in streamflow exceeded the measurement error. An apparent gain in streamflow was quantified for Subreach D between the most upstream and most downstream sites with useable streamflow values.

Subreach E extends along $55.0 \mathrm{mi}$ of the Rio Grande between sites 28 and 38. Streamflow was measured during February 5-11, 2006. Streamflow increased along the reach from $292 \mathrm{ft}^{3} / \mathrm{s}$ at site 28 to $450 \mathrm{ft}^{3} / \mathrm{s}$ at site 38 . Gains in streamflow were measured for two pairs of consecutive measurement sites, and on an overall basis, Subreach E was quantified as a gaining reach.

\section{Selected Water-Quality Observations}

Water-quality data were collected from 20 of the 38 streamflow measurement sites. In addition to collection of water-quality samples at sites in subreaches A-E, waterquality samples were collected upstream from subreach A.

\section{Salinity, Dissolved Solids, and Major Ions}

High concentrations of salinity in parts of the Rio Grande Basin have been noted for almost 100 years (Stabler, 1911). Salinity values measured in samples collected from subreaches A and B were fairly consistent; at sites $2-10$ in subreaches A and $\mathrm{B}$, salinity ranged from 1.66 to 1.82 parts per thousand (ppt) (table 5 at end of report). Beginning at site 13 in subreach $B$ and continuing downstream to site 38 in subreach $E$, salinity generally decreases; between sites 13 and 38, salinity ranged from $0.67 \mathrm{ppt}$ at site 38 to $1.17 \mathrm{ppt}$ at site 13 (table 5). Upstream from site 15 in subreach $C$, salinity values exceeded $1.00 \mathrm{ppt}$; downstream from site 15 salinity values were all less than 1.00 ppt.

Similar patterns of generally higher dissolved-solids and major-ion concentrations upstream from site 15 compared to downstream from site 15 were observed. Dissolved solids increase naturally in water through two processes: (1) salt concentration through evaporation and evapotranspiration, and (2) salt pickup, which occurs when surface water or groundwater acquires dissolved solids through dissolution (Anning and others, 2007). Conversely, dissolved-solids concentrations can decrease as a result of dilution from groundwater inflows, 


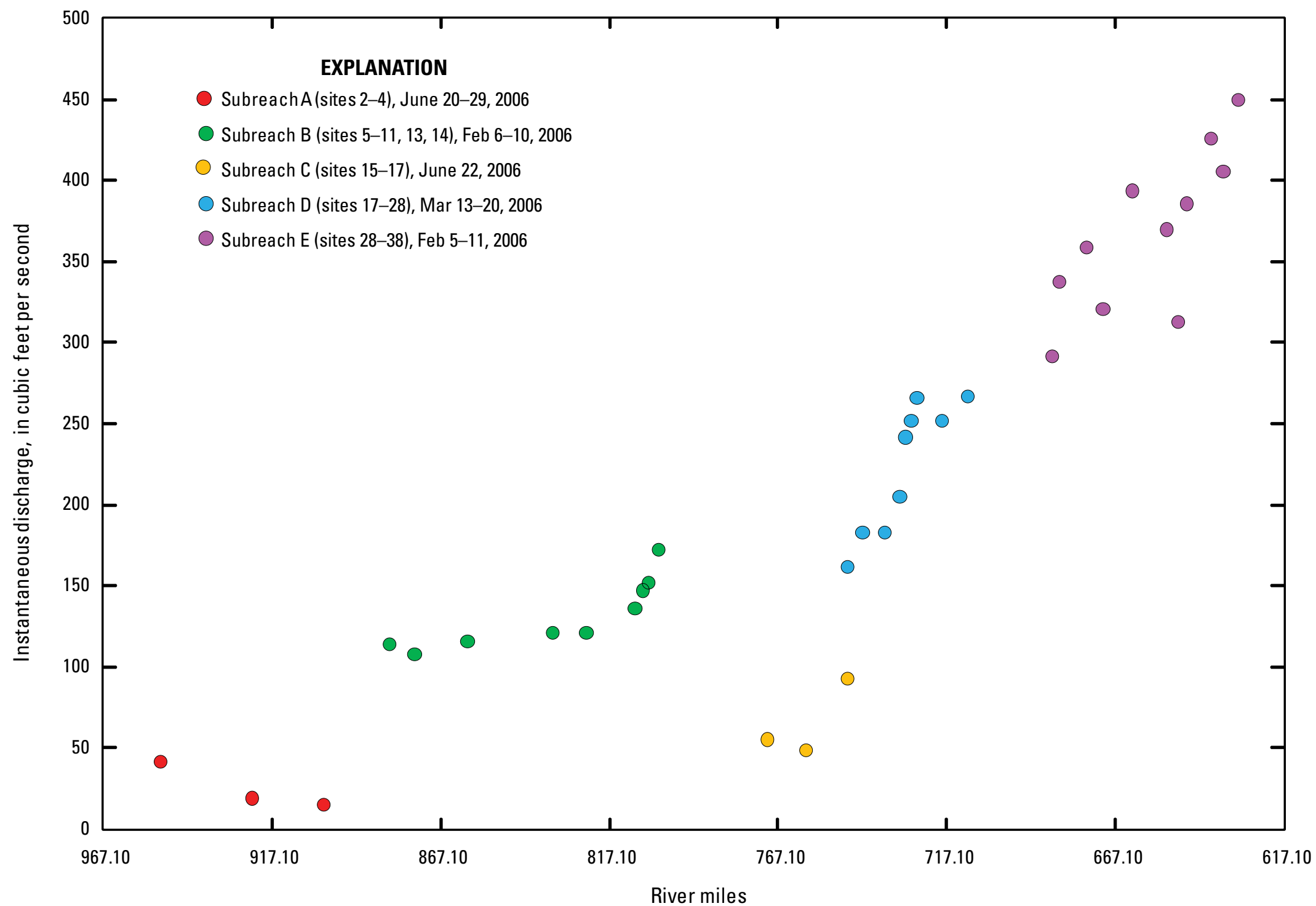

Figure 4. Instantaneous discharge for data-collection sites on the Rio Grande in subreaches A-E, Big Bend area, United States and Mexico, February-June 2006. 
which can have lower dissolved-solids concentrations compared to surface water depending on the bedrock the groundwater flows through (U.S. Environmental Protection Agency, 2012). Water with dissolved-solids concentrations exceeding 1,000 milligrams per liter $(\mathrm{mg} / \mathrm{L})$ generally is considered unsuitable for many purposes (Heath, 1983; Hem, 1985). Total dissolved-solid concentrations ranged from $2,560 \mathrm{mg} / \mathrm{L}$ at site 3 in subreach A to $886 \mathrm{mg} / \mathrm{L}$ at site 38 in downstream subreach E.

In subreaches A and $\mathrm{B}$, chloride and sulfate concentrations exceeded the TCEQ general use protection criteria (table 2). Chloride and sulfate concentrations decreased in the downstream direction in subreach $\mathrm{D}$. Chloride concentration in water-quality samples from subreaches $\mathrm{A}$ and $\mathrm{B}$ exceeded the TCEQ general use protection criteria of $300 \mathrm{mg} / \mathrm{L}$ (table 2), whereas, the maximum concentration from subreaches $\mathrm{C}$, $\mathrm{D}$, and $\mathrm{E}$ was $236 \mathrm{mg} / \mathrm{L}$ (table 3 ) at site 17 in subreach D (table 5). Sulfate concentrations generally decreased from site 2 in subreach A to site 38 in subreach E. Sulfate concentrations measured in samples collected from subreaches A and B consistently exceeded the $570 \mathrm{mg} / \mathrm{L}$ TCEQ general use protection criteria (table 2), whereas, the maximum concentration measured in samples collected from subreaches C, D, and E was $454 \mathrm{mg} / \mathrm{L}$ at site 15 in subreach C (table 5). Compared to subreaches $\mathrm{A}$ and $\mathrm{B}$, few water-quality data collected in subreaches C-E exceeded the TCEQ general use protection criteria (table 2); dissolved-solids, chloride, and sulfate concentrations were generally at their lowest levels in subreach $\mathrm{E}$ at site 38 (table 5).

\section{Nutrients}

Nitrogen and phosphorus are major nutrients affecting water quality. The most common forms of nitrogen include: (1) ammonia nitrogen $\left(\mathrm{NH}_{4}^{+}\right)$, (2) nitrate $\left(\mathrm{NO}_{3}^{-}\right)$, (3) nitrite $\left(\mathrm{NO}_{2}^{-}\right)$, and (4) a variety of organic nitrogen compounds (Wetzel, 1983). The primary source of soluble inorganic phosphorus is orthophosphate $\left(\mathrm{PO}_{4}^{-3}\right)$. Orthophosphate typically is lower in concentration than other nutrients.

The screening level for nitrate plus nitrite (reported as nitrogen) is $2.0 \mathrm{mg} / \mathrm{L}$ (table 2), and the nitrate plus nitrite concentrations measured in all samples were less than $0.9 \mathrm{mg} / \mathrm{L}$ (table 6 at end of report). All subreaches except subreach B had sites with detectable concentrations of nitrate plus nitrite. In contrast with many constituent concentrations that generally decreased in the downstream direction, nitrate plus nitrite values increased in the downstream direction. For example, nitrate plus nitrite concentrations increased from $0.331 \mathrm{mg} / \mathrm{L}$ at site 20 in subreach $\mathrm{D}$ to $0.642 \mathrm{mg} / \mathrm{L}$ at site 26 in subreach D. The screening levels for orthophosphate and phosphorous are 0.37 and $0.69 \mathrm{mg} / \mathrm{L}$, respectively (table 2). Measured concentrations of orthophosphate and phosphorous were less than the screening levels at all sites (table 6).

\section{Trace Elements}

Trace elements are inorganic chemicals usually found in small concentrations (typically less than $1.0 \mathrm{mg} / \mathrm{L}$ ) in water. Some trace elements have been linked to certain geologic formations and land uses, including mining and agriculture (Lambert and others, 2008). Trace-element concentrations in water samples were determined for arsenic, boron, iron, lithium, selenium, strontium, and vanadium. Arsenic and selenium concentrations in all samples were less than the TCEQ aquatic life use protection and human health criteria (table 2). Among the trace elements shown in table 7 (at end of report), the decrease in concentration downstream within each reach was most pronounced for strontium and boron. Strontium concentrations generally decreased in downstream direction, ranging from a maximum of 3,690 micrograms per liter $(\mu \mathrm{g} / \mathrm{L})$ at site 2 to a minimum of $2,010 \mu \mathrm{g} / \mathrm{L}$ at site 38 . Boron concentrations also generally decreased in downstream direction, ranging from a maximum of $607 \mu \mathrm{g} / \mathrm{L}$ at site 2 to a minimum of $220 \mu \mathrm{g} / \mathrm{L}$ at site 38 . For other trace elements, a pattern between downstream site order and concentration was not evident (table 7).

\section{Stable Isotopes}

Oxygen has three stable isotopes: oxygen-16, oxygen-17, and oxygen-18 $\left({ }^{16} \mathrm{O},{ }^{17} \mathrm{O}\right.$, and $\left.{ }^{18} \mathrm{O}\right)$ (Faure, 1986); nitrogen has two stable isotopes: nitrogen-14 $\left({ }^{14} \mathrm{~N}\right)$ and nitrogen-15 $\left({ }^{15} \mathrm{~N}\right)$ (Kendall and Aravena, 2000). Stable isotope concentrations are reported in per mil, the ratio of stable-isotope abundances of an element in a sample to those of a standard material. For example, nitrogen isotopes are reported relative to the nitrogen gas $\left(\mathrm{N}_{2}\right)$ concentration in atmospheric air (Kendall and Aravena, 2000). Stable isotope results from sites 17, 26, 29, 32,36 , and 38 collected from subreaches D and E were generally similar, and markedly different compared to the stable isotope results obtained from site 3 in subreach A (appendix 1). Differences in groundwater inflows in subreach A compared to subreaches $\mathrm{D}$ and $\mathrm{E}$ might be causing the different isotope results observed during this study.

\section{Summary}

The Rio Grande/Rio Bravo del Norte (hereinafter Rio Grande) forms the boundary between Texas in the United States and Chihuahua and Coahuila in Mexico. The study area encompasses a 336.3-mile reach of the Rio Grande from near Presidio to near Langtry, Texas, in the Big Bend area along the United States-Mexico border. Few historical streamflow and water-quality data are available to characterize this reach of the Rio Grande. The U.S. Geological Survey (USGS), in cooperation with the National Park Service and the Texas Commission on Environmental Quality (TCEQ), collected streamflow 
data from near Presidio to near Langtry, Texas, to characterize streamflow gains and losses. Streamflow gains and losses and water-quality properties were measured in five subreaches of the Rio Grande during three synoptic surveys done between February and June 2006 and at one site upstream from the five subreaches. Water-quality data were compared to available TCEQ or screening levels in the absence of State standards.

Streamflow was measured at 38 sites and water-quality samples were collected at 20 sites in February, March, and June 2006. Water-quality data were analyzed for selected physical properties and constituents including salinity, dissolved solids, major ions, nutrients, trace elements, and stable isotopes. Streamflow gains and losses over the course of the Rio Grande from near Presidio to near Langtry were measured indirectly by computing the differences in measured streamflow between sites in five subreaches of the Rio Grande. The potential errors associated with each streamflow measurement for a given site were compared to estimate streamflow gain or loss within each subreach.

Water-quality data were collected from 20 of the 38 sites in the study area. Water-quality samples were analyzed by the USGS National Water Quality Laboratory for salinity, dissolved solids, major ions, nutrients, and trace elements; samples were analyzed by the USGS Stable Isotope Laboratory for stable isotopes.

Streamflow gain and loss and water-quality constituent concentrations were evaluated for each subreach. Dissolved solids, chloride, and sulfate, concentrations measured in subreach A, which was predominately losing reach, exceeded the TCEQ general use protection criteria. Subreach B is the longest reach within the study area, and small downstream increases in streamflow were measured in this gaining reach. Dissolved-solids, chloride, and sulfate concentrations decreased along the reach, however, concentrations of these constituents exceeded the TCEQ general use protection criteria at all sites within subreach B. Subreaches C, D, and E were gaining reaches in the lower part of the study area. Salinity values measured in samples collected from subreaches $A$ and B were fairly consistent; at sites $2-10$ in subreaches A and $\mathrm{B}$, salinity ranged from 1.66 to 1.82 parts per thousand (ppt). Beginning at site 13 in subreach $B$ and continuing downstream to site 38 in subreach E, salinity generally decreases; between sites 13 and 38, salinity ranged from $0.67 \mathrm{ppt}$ at site 38 to $1.17 \mathrm{ppt}$ at site 13 . Upstream from site 15 in subreach C, salinity values exceeded $1.00 \mathrm{ppt}$; downstream from site 15 , salinity values were all less than $1.00 \mathrm{ppt}$. Chloride, sulfate, and dissolved-solids concentrations decreased downstream along each of the subreaches. None of the constituents measured in subreaches C, D, and E exceeded applicable TCEQ water-quality criteria. Chloride, sulfate, and dissolved-solids concentrations were at their lowest levels in subreach $\mathrm{E}$ at site 38. Concentrations of arsenic and selenium were below the TCEQ criteria and screening levels for all samples.

\section{References}

Adams, D.K., and Comrie, A.C., 1997, The North American monsoon: Bulletin of the American Meteorological Society, v. 78 , no. 10 , p. $2,197-2,213$.

Anning, D.W., Bauch, N.J., Gerner, S.J., Flynn, M.E., Hamlin, S.N., Moore, S.J., Schaefer, D.H., Anderholm, S.K., and Spangler, L.E., 2007, Dissolved solids in basin-fill aquifers and streams in the Southwestern United States: U.S. Geological Survey Scientific Investigations Report 2006-5316, $168 \mathrm{p}$.

Ashworth, J.B., and Hopkins, Janie, 1995, Aquifers of Texas: Texas Water Development Board Report 345, 69 p.

Baker, E.T., Jr., and Buszka, P.M., 1993. Hydrogeology, geochemistry, and quality of water of the Basin and Oak Spring areas of the Chisos Mountains, Big Bend National Park: U.S. Geological Survey Water-Resources Investigation Report 93-4112, 76 p.

Bartolino, J.R., and Cole, J.C., 2002, Ground-water resources of the Middle Rio Grande Basin, New Mexico: U.S. Geological Survey Circular 1222, 132 p.

Berry, M.E., and Williams, V.S., 2008, Surficial deposits of Big Bend National Park, in Gray, J.E., and Page, W.R., eds., Geological, geochemical, and geophysical studies by the U.S. Geological Survey in Big Bend National Park, Texas: U.S. Geological Survey Circular 1327, 93 p.

Clark, I.D., and Fritz, Peter, 1997, Environmental isotopes in hydrogeology: Boca Raton, Fla., CRC Press, 328 p.

Coplen, T.B., Wildman, J.D., and Chen, J., 1991, Improvements in the gaseous hydrogen-water equilibration technique for hydrogen isotope ratio analysis: Analytical Chemistry, v. 63, p. 910-912.

Epstein, S., and Mayeda, T., 1953, Variation of $\mathrm{O}^{18}$ content of waters from natural sources: Geochimica et Cosmochimica Acta, v. 4, p. 213-224.

Environmental Systems Research Institute, Inc., 2009, ArcGIS Desktop 9.2-Data and Maps: Environmental Systems Research Institute, Inc., Redlands, Calif., accessed August 24, 2010, at http://www.esri.com/.

Faure, Gunter, 1986, Principles of isotope geology; New York, John Wiley and Sons, Inc., 589 p.

Fishman, M.J., 1993, Methods of analysis by the U.S. Geological Survey National Water Quality Laboratory-Determination of inorganic and organic constituents in water and fluvial sediments: U.S. Geological Survey Open-File Report 93-125, $217 \mathrm{p}$. 
Fishman, M.J., and Friedman, L.C., eds., 1989, Methods for determination of inorganic substances in water and fluvial sediments: U.S. Geological Survey Techniques of WaterResources Investigations, book 5, chap. A1, 545 p.

Garbarino, J.R., 1999, Methods of analysis by the U.S. Geological Survey National Water Quality LaboratoryDetermination of dissolved arsenic, boron, lithium, selenium, strontium, thallium, and vanadium using inductively coupled plasma-mass spectrometry: U.S. Geological Survey Open-File Report 99-093, 31 p.

Garbarino, J.R., Kanagy, L.K., and Cree, M.E., 2006, Determination of elements in natural-water, biota, sediment and soil samples using collision/reaction cell inductively coupled plasma-mass spectrometry: U.S. Geological Survey Techniques and Methods 5-B1, $87 \mathrm{p}$.

Garbarino, J.R., and Struzeski, T.M., 1998, Methods of analysis by the U.S. Geological Survey National Water Quality Laboratory-Determination of elements in wholewater digests using inductively coupled plasma-optical emission spectrometry and inductively coupled plasmamass spectrometry: U.S. Geological Survey Open-File Report 98-165, $101 \mathrm{p}$.

Garbarino, J.R., and Taylor, H.E., 1996, Inductively coupled plasma-mass spectrometric method for the determination of dissolved trace elements in natural water: U.S. Geological Survey Open-File Report 94-358, 49 p.

Gray, J.E., and Page, W.R., eds., 2008, Geological, geochemical, and geophysical studies by the U.S. Geological Survey in Big Bend National Park, Texas: U.S. Geological Survey Circular 1327, 93 p.

Heath, R.C., 1983, Basic ground-water hydrology: U.S. Geological Survey Water-Supply Paper 2220, 84 p.

Hem, J.D., 1985, Study and interpretation of chemical characteristics of natural water ( $3 d$ ed.): U.S. Geological Survey Water-Supply Paper 2254, 263 p.

International Boundary and Water Commission, 2003, 2003 Regional assessment of water quality in the Rio Grande Basin: Report of the International Boundary and Water Commission, $142 \mathrm{p}$.

International Boundary and Water Commission, 2005, Flow of the Rio Grande and related data: Water Bulletin Number 75, $140 \mathrm{p}$.

International Boundary and Water Commission, 2008, Regional assessment of water quality - Rio Grande Basin: Texas Clean Rivers Program, International Boundary and Water Commission, United States Section, 96 p. (Also available at http://www.ibwc.state.gov/CRP/ documents/2008BSR_IBWC.pdf.)
Kendall, Carol, and Aravena, R., 2000, Nitrate isotopes in groundwater systems, in Cook, P, and Herczeg, A.L., eds., Environmental tracers in subsurface hydrology: Norwell, Mass., Kluwer Academic Publishers, p. 261-297.

Kendall, Carol, and McDonnell, J.J., eds., 1998, Isotope tracers in catchment hydrology: Elsevier, 839 p.

Lambert, R.B., Kolbe, C.M., and Belzer, W., 2008, Quality of water and sediment in streams affected by historical mining, and quality of mine tailings, in the Rio Grande/Río Bravo Basin, Big Bend area of the United States and Mexico: U.S. Geological Survey Scientific Investigations Report 2008-5032, 45 p.

National Climatic Data Center, 2011, Climatography of the United States, 1971-2000: accessed June 27, 2011, at http://hurricane.ncdc.noaa.gov/cgi-bin/climatenormals/ climatenormals.pl.

National Park Service, 2012, Big Bend National Park, TexasPark map: accessed April 24, 2012, at http:/www.nps.gov/ bibe/index.htm.

Oberg, K.A., Morlock, S.E., and Caldwell, W.S., 2005, Quality-assurance plan for discharge measurements using acoustic Doppler current profilers: U.S. Geological Survey Scientific Investigations Report 2005-5183, 35 p.

Oden, J.H., Brown, D.W., and Oden, T.D., 2011, Groundwater quality of the Gulf Coast aquifer system, Houston, Texas, 2010: U.S. Geological Survey Data Series 598, 64 p.

Patrick, Ruth, 2003, Rivers of the United States, vol. V, part B-The Gulf of Mexico: New York, John Wiley and Sons, Inc., $260 \mathrm{p}$.

Patton, C.J., and Truitt, E.P., 1992, Methods of analysis by the U.S. Geological Survey National Water Quality Laboratory-Determination of total phosphorus by a Kjeldahl digestion method and an automated colorimetric finish that includes dialysis: U.S. Geological Survey Open-File Report 92-146, 39 p.

Patton, C.J., and Truitt, E.P., 2000, Methods of analysis by the U.S. Geological Survey National Water Quality Laboratory-Determination of ammonium plus organic nitrogen by a Kjeldahl digestion method and an automated photometric finish that includes digest cleanup by gas diffusion: U.S. Geological Survey Open-File Report 00-170, 31 p.

Rantz, S.E., and others, 1982, Measurement and computation of streamflow-Volume 1. Measurement of stage and discharge: U.S. Geological Survey Water-Supply Paper 2175, chap. 5, p. 79-183.

Reeves, R.D., and Small, T.A., 1973, Ground-water resources of Val Verde County, Texas: Texas Water Development Board Report 172, 140 p. 
Sauer, R.M., Jr., and Meyer, R.W., 1992, Determination of error in individual discharge measurements: U.S. Geological Survey Open-File Report 92-144, 21 p.

Schmandt, J., Aquilar-Barajas, I., Mathis, M., Armstrong, N., Chapa-Alemán, L., Contreras-Balderas, S, Edwards, R., Garcia-Ramirez, M.E., Hazleton, J., Lozano-Vilano, M., Navar-Chaidez, J., Vogel, E, and Ward, G., 2000, Water and sustainable development in the binational lower Rio Grande /Río Bravo Basin-Final report to Environmental Protection Agency: NSF Water and Watersheds grant program (Grant No. R 824799-01-0), The Woodlands, Tex., Houston Advance Research Center, Center for Global Studies.

Secretaría de Medio Ambiente y Recursos Naturales, 2012, Área de Protección de Flora y Fauna: accessed April 24, 2012, at http://www.conanp.gob.mx/.

Stabler, Herman, 1911, Some stream waters of the western United States, with chapters on Sediment carried by the Rio Grande and the industrial application of water analyses: U.S. Geological Survey Water-Supply Paper 274, 188 p.

Texas Commission on Environmental Quality, 2002, Texas water-quality inventory, Rio Grande above Amistad Reservoir: accessed June 23, 2010, at http://www. tceq.info/ assets/public/compliance/monops/water/ assessments/02_2306_fact.pdf.

Texas Commission on Environmental Quality, 2010, 2010 Texas surface water quality standards: accessed June 29, 2011, at http://www.tceq.texas.gov/waterquality/ standards/2010standards.html.

Turco, M.J., East, J.W., and Milburn, M.S., 2007, Base flow (1966-2005) and streamflow gain and loss (2006) of the Brazos River, McLennan County to Fort Bend County,
Texas: U.S. Geological Survey Scientific Investigations Report 2007-5286, 27 p.

Turnipseed, D.P., and Sauer, V.B., 2010, Discharge measurements at gaging stations: U.S. Geological Survey Techniques and Methods, book 3, chap. A8, 87 p.

U.S. Army Corps of Engineers, 2008, Forgotten reach of the Rio Grande, Fort Quitman to Presidio, Texas, Section 729: Prepared by Albuquerque District for Texas Commission on Environmental Quality.

U.S. Environmental Protection Agency, 2012, Water monitoring and assessment-What is conductivity and why is it important?: accessed May 16, 2012, at http://water.epa.gov/ type/rsl/monitoring/vms59.cfm.

U.S. Geological Survey, variously dated, National field manual for the collection of water-quality data: U.S. Geological Survey Techniques of Water-Resources Investigations, book 9, chap. A1-A9. (Also available at http://pubs.water. usgs.gov/twri9A.)

U.S. Geological Survey, 2012, National Water Information System (NWISWeb) [for Texas]: U.S. Geological Survey database, accessed April 27, 2012, at http://waterdata.usgs. gov/tx/nwis/nwis.

Wagner, R.J., Mattraw, H.C., Ritz, G.F., and Smith, B.A., 2000, Guidelines and standard procedures for continuous water-quality monitors - Site selection, field operation, calibration, record computation, and reporting: U.S. Geological Survey Water-Resources Investigations Report 2000-4252, $53 \mathrm{p}$.

Wetzel, R.G., 1983, Limnology (2d ed.): Philadelphia, Pa., W.B. Saunders Co., 860 p. 
Table 1. Sites at which measurements for streamflow gain and loss computation were made on the Rio Grande and one tributary, from near Presidio to near Langtry, Texas, Big Bend area, United States and Mexico, February-June 2006.

[USGS, U.S. Geological Survey; IBWC, International Boundary and Water Commission; fts/s, cubic feet per second; Q, instantaneous discharge measurement; RPD, relative percent difference; --, not applicable; $Q^{\mathrm{e}}$, discharge estimated from continous streamflow records from nearest IBWC streamflow-gaging station (fig. 2); QW, water-quality sample; QA, water-quality quality-assurance sample; Fair, Q uncertainty 8 percent; BBNP, Big Bend National Park; Poor, Q uncertainty greater than 8 percent; Good, Q uncertainty 5 percent]

\begin{tabular}{|c|c|c|c|c|c|c|c|c|c|c|c|c|c|c|c|}
\hline \multirow[t]{2}{*}{$\begin{array}{c}\text { Site } \\
\text { num- } \\
\text { ber } \\
\text { (fig. 2) }\end{array}$} & \multirow[t]{2}{*}{ Site name } & \multirow[t]{2}{*}{$\begin{array}{l}\text { USGS or IBWC' } \\
\text { streamflow- } \\
\text { gaging station } \\
\text { number }\end{array}$} & \multirow[t]{2}{*}{$\begin{array}{l}\text { Sub- } \\
\text { reach }^{2} \\
\text { (fig. 2) }\end{array}$} & \multirow[t]{2}{*}{$\begin{array}{l}\text { Sample } \\
\text { date }\end{array}$} & \multirow[t]{2}{*}{$\begin{array}{l}\text { River } \\
\text { mile }\end{array}$} & \multicolumn{2}{|c|}{$\begin{array}{l}\text { Discharge } \\
\left(\mathrm{ft}^{3} / \mathrm{s}\right)\end{array}$} & \multicolumn{2}{|c|}{$\begin{array}{c}\text { Discharge } \\
\text { measure- } \\
\text { ment } \\
\text { qualifier } \\
\end{array}$} & \multirow[t]{2}{*}{$\mathbf{R P D}^{3}$} & \multirow[t]{2}{*}{$\begin{array}{c}\text { Mean } \\
\text { dis- } \\
\text { charge } \\
\left(\mathrm{ft}^{3} / \mathbf{s}\right)\end{array}$} & \multirow[t]{2}{*}{$\begin{array}{c}\text { Type } \\
\text { of data } \\
\text { collected }\end{array}$} & \multirow[t]{2}{*}{$\begin{array}{l}\text { Latitude } \\
\text { (decimal } \\
\text { degrees) }\end{array}$} & \multirow[t]{2}{*}{$\begin{array}{l}\text { Longi- } \\
\text { tude } \\
\text { (decimal } \\
\text { degrees) }\end{array}$} & \multirow[t]{2}{*}{$\begin{array}{c}\text { Seg- } \\
\text { ment } \\
\text { (fig. 2) }\end{array}$} \\
\hline & & & & & & $0_{1}$ & $\mathbf{O}_{2}$ & $0_{1}$ & $\mathbf{O}_{2}$ & & & & & & \\
\hline 1 & $\begin{array}{l}\text { Rio Grande above Rio Conchos near } \\
\text { Presidio, Tex. }\end{array}$ & ${ }^{1} 08371500$ & $\mathrm{U}^{4}$ & $6 / 29 / 2006$ & 967.1 & 4.06 & -- & -- & -- & -- & -- & $\mathrm{Q}^{\mathrm{e}}, \mathrm{QW}$ & 29.6237 & 104.4742 & 2307 \\
\hline 2 & $\begin{array}{l}\text { Rio Grande below Rio Conchos near } \\
\text { Presidio, Tex. }\end{array}$ & ${ }^{1} 08374200$ & A & $6 / 29 / 2006$ & 950.1 & 41.2 & -- & -- & -- & -- & -- & $\mathrm{Q}^{\mathrm{e}}, \mathrm{QW}$ & 29.5196 & 104.2866 & 2306 \\
\hline 3 & $\begin{array}{l}\text { Rio Grande at Rancherias Rapids near } \\
\text { Redford, Tex. }\end{array}$ & ${ }^{1} 08374325$ & A & $6 / 20 / 2006$ & 923.2 & 19.1 & 18.2 & Fair & Fair & 1.2 & 18.7 & Q, QW & 29.3371 & 104.0553 & 2306 \\
\hline 4 & Rio Grande above Lajitas, Tex. & 291555103465900 & A & $6 / 20 / 2006$ & 902.0 & 15.5 & 14.4 & Fair & Fair & 1.8 & 15.0 & $\mathrm{Q}, \mathrm{QW}$ & 29.2653 & 103.7833 & 2306 \\
\hline 5 & $\begin{array}{l}\text { Rio Grande at Santa Elena Canyon, BBNP, } \\
\text { Tex. }\end{array}$ & 290956103363600 & $\mathrm{~B}$ & $2 / 6 / 2006$ & 882.4 & 114 & -- & Fair & -- & -- & -- & Q, QW & 29.1655 & 103.6101 & 2306 \\
\hline 6 & Rio Grande near Castolon, BBNP, Tex. & 08374550 & B & $2 / 6 / 2006$ & 875.1 & 109 & 108 & Fair & Fair & 0.2 & 109 & $\mathrm{Q}, \mathrm{QW}$ & 29.1380 & 103.5249 & 2306 \\
\hline 7 & $\begin{array}{l}\text { Rio Grande at Johnson Ranch near Casto- } \\
\text { lon, Tex. }\end{array}$ & ${ }^{1} 08375000$ & $\mathrm{~B}$ & $2 / 7 / 2006$ & 859.2 & 114 & 117 & Fair & Fair & 0.6 & 116 & $\mathrm{Q}, \mathrm{QW}$ & 29.0349 & 103.3921 & 2306 \\
\hline 8 & $\begin{array}{l}\text { Rio Grande at Talley Campground, BBNP, } \\
\text { Tex. }\end{array}$ & 285858103110000 & $\mathrm{~B}$ & $2 / 8 / 2006$ & 834.1 & 120 & 122 & Fair & Fair & 0.4 & 121 & $\mathrm{Q}, \mathrm{QW}$ & 28.9829 & 103.1833 & 2306 \\
\hline 9 & $\begin{array}{l}\text { Rio Grande at Solis Campground, BBNP, } \\
\text { Tex. }\end{array}$ & 290239103061900 & $\mathrm{~B}$ & $2 / 8 / 2006$ & 824.1 & 117 & 125 & Fair & Fair & 1.7 & 121 & Q & 29.0442 & 103.1053 & 2306 \\
\hline 10 & $\begin{array}{l}\text { Rio Grande at La Clocha Campground, } \\
\text { BBNP, Tex. }\end{array}$ & 290855103002800 & $\mathrm{~B}$ & $2 / 9 / 2006$ & 809.7 & 139 & 132 & Fair & Fair & 1.3 & 136 & $\begin{array}{l}\text { Q, QW, } \\
\text { QA }\end{array}$ & 29.1486 & 103.0078 & 2306 \\
\hline 11 & $\begin{array}{l}\text { Rio Grande upstream from Hot Springs, } \\
\text { BBNP, Tex. }\end{array}$ & 291039102595000 & $\mathrm{~B}$ & $2 / 10 / 2006$ & 807.4 & 146 & 148 & Fair & Fair & 0.3 & 147 & Q & 29.1774 & 102.9972 & 2306 \\
\hline 12 & $\begin{array}{l}\text { Hot Springs tributary near Rio Grande } \\
\text { Village, BBNP, Tex. }\end{array}$ & 291055102593100 & $\mathrm{~B}$ & $2 / 10 / 2006$ & 806.9 & 0.64 & -- & Fair & -- & -- & -- & Q & 29.1819 & 102.9919 & 2306 \\
\hline 13 & Rio Grande at Rio Grande Village, Tex. & 08375300 & B & $2 / 9 / 2006$ & 805.6 & 150 & 155 & Fair & Fair & 0.8 & 153 & $\mathrm{Q}, \mathrm{QW}$ & 29.1855 & 102.9731 & 2306 \\
\hline 14 & $\begin{array}{l}\text { Rio Grande at Boquillas Crossing, BBNP, } \\
\text { Tex. }\end{array}$ & 291119102564400 & $\mathrm{~B}$ & $2 / 10 / 2006$ & 802.7 & 172 & 173 & Fair & Fair & 0.1 & 173 & Q & 29.1886 & 102.9456 & 2306 \\
\hline 15 & Rio Grande at La Linda, Mexico & 292658102492300 & $\mathrm{C}$ & $6 / 22 / 2006$ & 770.2 & 56.1 & 54.7 & Fair & Fair & 0.6 & 55.4 & Q, QW & 29.4493 & 102.8230 & 2306 \\
\hline 16 & $\begin{array}{l}\text { Rio Grande at Maravillas Creek near } \\
\text { Sanderson, Tex. }\end{array}$ & 293340102463700 & $\mathrm{C}$ & $6 / 22 / 2006$ & 758.7 & 49.0 & -- & Fair & -- & -- & -- & Q & 29.5611 & 102.7769 & 2306 \\
\hline 17 & $\begin{array}{l}\text { Rio Grande at Taylor's Farm near } \\
\text { Sanderson, Tex. }\end{array}$ & 294020102415900 & $\mathrm{C}$ & $6 / 22 / 2006$ & 746.5 & 94.0 & 91.3 & Fair & Fair & 0.7 & 92.6 & Q, QW & 29.6724 & 102.6996 & 2306 \\
\hline
\end{tabular}


Table 1. Sites at which measurements for streamflow gain and loss computation were made on the Rio Grande and one tributary, from near Presidio to near Langtry, Texas, Big Bend area, United States and Mexico, February-June 2006.-Continued

[USGS, U.S. Geological Survey; IBWC, International Boundary and Water Commission; ft 3 /s, cubic feet per second; Q, instantaneous discharge measurement; RPD, relative percent difference; --, not applicable; $\mathrm{Q}^{\mathrm{e}}$, discharge estimated from continous streamflow records from nearest IBWC streamflow-gaging station (fig. 2); QW, water-quality sample; QA, water-quality quality-assurance sample;

Fair, Q uncertainty 8 percent; BBNP, Big Bend National Park; Poor, Q uncertainty greater than 8 percent; Good, Q uncertainty 5 percent]

\begin{tabular}{|c|c|c|c|c|c|c|c|c|c|c|c|c|c|c|c|}
\hline \multirow[t]{2}{*}{$\begin{array}{l}\text { Site } \\
\text { num- } \\
\text { ber } \\
\text { (fig. 2) }\end{array}$} & \multirow[t]{2}{*}{ Site name } & \multirow[t]{2}{*}{$\begin{array}{l}\text { USGS or IBWC' } \\
\text { streamflow- } \\
\text { gaging station } \\
\text { number }\end{array}$} & \multirow[t]{2}{*}{$\begin{array}{l}\text { Sub- } \\
\text { reach }^{2} \\
\text { (fig. 2) }\end{array}$} & \multirow[t]{2}{*}{$\begin{array}{l}\text { Sample } \\
\text { date }\end{array}$} & \multirow[t]{2}{*}{$\begin{array}{l}\text { River } \\
\text { mile }\end{array}$} & \multicolumn{2}{|c|}{$\begin{array}{l}\text { Discharge } \\
\left(\mathrm{ft}^{3} / \mathbf{s}\right)\end{array}$} & \multicolumn{2}{|c|}{$\begin{array}{c}\text { Discharge } \\
\text { measure- } \\
\text { ment } \\
\text { qualifier }\end{array}$} & \multirow[t]{2}{*}{$\mathbf{R P D}^{3}$} & \multirow[t]{2}{*}{$\begin{array}{c}\text { Mean } \\
\text { dis- } \\
\text { charge } \\
\left(\mathrm{ft}^{3} / \mathbf{s}\right)\end{array}$} & \multirow[t]{2}{*}{$\begin{array}{c}\text { Type } \\
\text { of data } \\
\text { collected }\end{array}$} & \multirow[t]{2}{*}{$\begin{array}{l}\text { Latitude } \\
\text { (decimal } \\
\text { degrees) }\end{array}$} & \multirow[t]{2}{*}{$\begin{array}{l}\text { Longi- } \\
\text { tude } \\
\text { (decimal } \\
\text { degrees) }\end{array}$} & \multirow[t]{2}{*}{$\begin{array}{r}\text { Seg- } \\
\text { ment } \\
\text { (fig. } 2\end{array}$} \\
\hline & & & & & & $\mathbf{0}_{1}$ & $\mathbf{O}_{2}$ & $\mathbf{0}_{1}$ & $\mathbf{O}_{2}$ & & & & & & \\
\hline 17 & $\begin{array}{l}\text { Rio Grande at Taylor's Farm near } \\
\text { Sanderson, Tex. }\end{array}$ & 294020102415900 & $\mathrm{D}$ & $3 / 13 / 2006$ & 746.5 & 166 & 157 & Fair & Fair & 1.4 & 162 & Q, QW & 29.6724 & 102.6996 & 2306 \\
\hline 18 & Rio Grande above Big Canyon, Tex. & 294319102412100 & $\mathrm{D}$ & $3 / 14 / 2006$ & 742.2 & 183 & -- & Fair & -- & -- & -- & Q & 29.7219 & 102.6892 & 2306 \\
\hline 19 & Rio Grande above Bear Canyon, Tex. & 294449102365300 & $\mathrm{D}$ & $3 / 14 / 2006$ & 735.6 & 183 & -- & Fair & -- & -- & -- & Q & 29.7469 & 102.6147 & 2306 \\
\hline 20 & $\begin{array}{l}\text { Rio Grande above Silber Canyon near } \\
\text { Sanderson, Tex. }\end{array}$ & 294613102335500 & $\mathrm{D}$ & $3 / 15 / 2006$ & 731.1 & 205 & 206 & Fair & Fair & 0.1 & 206 & Q, QW & 29.7703 & 102.5653 & 2306 \\
\hline 21 & Rio Grande below Silber Canyon, Tex. & 294457102331600 & $\mathrm{D}$ & $3 / 15 / 2006$ & 729.4 & 242 & -- & Fair & Fair & -- & -- & Q & 29.7492 & 102.5544 & 2306 \\
\hline 22 & Rio Grande below Hot Springs, Tex. & 294517102320200 & $\mathrm{D}$ & $3 / 15 / 2006$ & 727.8 & 239 & 264 & Fair & Fair & 2.5 & 252 & Q & 29.7547 & 102.5339 & 2306 \\
\hline 23 & Rio Grande at Caballo Blanco, Tex. & 294604102304600 & $\mathrm{D}$ & $3 / 16 / 2006$ & 726.1 & 266 & -- & Fair & -- & -- & -- & Q & 29.7678 & 102.5128 & 2306 \\
\hline 24 & $\begin{array}{l}\text { Rio Grande below Rodeo Rapids near } \\
\text { Sanderson, Tex. }\end{array}$ & 294625102262700 & $\mathrm{D}$ & $3 / 16 / 2006$ & 718.6 & 252 & -- & Fair & -- & -- & -- & Q, QW & 29.7736 & 102.4407 & 2306 \\
\hline 25 & $\begin{array}{l}\text { Rio Grande below Lower Madison } \\
\text { Canyon, Tex. }\end{array}$ & 294759102223800 & $\mathrm{D}$ & $3 / 17 / 2006$ & 711.2 & 267 & -- & Fair & Fair & -- & -- & Q & 29.7997 & 102.3772 & 2306 \\
\hline 26 & $\begin{array}{l}\text { Rio Grande below Panther Gulch near } \\
\text { Sanderson, Tex. }\end{array}$ & 295057102214000 & $\mathrm{D}$ & $3 / 18 / 2006$ & 707.4 & 271 & 285 & Fair & Fair & 1.3 & 278 & Q, QW & 29.8491 & 102.3611 & 2306 \\
\hline 27 & $\begin{array}{l}\text { Rio Grande below Middle Watering Hole, } \\
\text { Tex. }\end{array}$ & 295053102142200 & $\mathrm{D}$ & $3 / 19 / 2006$ & 694.5 & ${ }^{5} 445$ & -- & Poor & -- & -- & -- & Q & 29.8481 & 102.2394 & 2306 \\
\hline 28 & Rio Grande at Dryden Crossing, Tex. & 294833102085400 & $\mathrm{D}$ & $3 / 20 / 2006$ & 685.8 & 5393 & -- & Fair & -- & -- & -- & Q & 29.8092 & 102.1483 & 2306 \\
\hline 28 & Rio Grande at Dryden Crossing, Tex. & 294833102085400 & $\mathrm{E}$ & $2 / 5 / 2006$ & 685.8 & 292 & -- & Fair & -- & -- & -- & Q & 29.8092 & 102.1483 & 2306 \\
\hline 29 & $\begin{array}{l}\text { Rio Grande above Shafter Crossing near } \\
\text { Dryden, Tex. }\end{array}$ & 294808102071000 & $\mathrm{E}$ & $2 / 5 / 2006$ & 683.7 & 338 & -- & Fair & -- & -- & -- & Q, QW & 29.8023 & 102.1195 & 2306 \\
\hline 30 & Rio Grande at Martin's Canyon, Tex. & 294808102013400 & $\mathrm{E}$ & $2 / 6 / 2006$ & 675.6 & 359 & -- & Fair & -- & -- & -- & Q & 29.8022 & 102.0262 & 2306 \\
\hline 31 & $\begin{array}{l}\text { Rio Grande above Indian Creek near } \\
\text { Dryden, Tex. }\end{array}$ & 294857101583300 & $\mathrm{E}$ & $2 / 7 / 2006$ & 670.8 & 321 & -- & Fair & -- & -- & -- & Q & 29.8160 & 101.9759 & 2306 \\
\hline 32 & $\begin{array}{l}\text { Rio Grande above Lozier Canyon near } \\
\text { Dryden, Tex. }\end{array}$ & 294743101524500 & $\mathrm{E}$ & $2 / 8 / 2006$ & 662.0 & 394 & -- & Fair & -- & -- & -- & Q, QW & 29.7952 & 101.8791 & 2306 \\
\hline 33 & $\begin{array}{l}\text { Rio Grande below Lozier Canyon near } \\
\text { Dryden, Tex. }\end{array}$ & 294646101475800 & $\mathrm{E}$ & $2 / 9 / 2006$ & 652.0 & 370 & -- & Fair & -- & -- & -- & Q & 29.7795 & 101.7996 & 2306 \\
\hline 34 & $\begin{array}{l}\text { Rio Grande at Foster Ranch near Langtry, } \\
\text { Tex. }\end{array}$ & ${ }^{1} 08377200$ & $\mathrm{E}$ & $2 / 8 / 2006$ & 648.7 & 313 & -- & -- & -- & -- & -- & $\begin{array}{l}\mathrm{Q}^{\mathrm{e}}, \mathrm{QW} \\
\mathrm{QA}\end{array}$ & 29.7808 & 101.7560 & 2305 \\
\hline
\end{tabular}


Table 1. Sites at which measurements for streamflow gain and loss computation were made on the Rio Grande and one tributary, from near Presidio to near Langtry, Texas, Big Bend area, United States and Mexico, February-June 2006.-Continued

[USGS, U.S. Geological Survey; IBWC, International Boundary and Water Commission; $\mathrm{ft}^{3} / \mathrm{s}$, cubic feet per second; Q, instantaneous discharge measurement; RPD, relative percent difference; --, not applicable; $\mathrm{Q}^{\mathrm{e}}$, discharge estimated from continous streamflow records from nearest IBWC streamflow-gaging station (fig. 2); QW, water-quality sample; QA, water-quality quality-assurance sample; Fair, Q uncertainty 8 percent; BBNP, Big Bend National Park; Poor, Q uncertainty greater than 8 percent; Good, Q uncertainty 5 percent]

\begin{tabular}{|c|c|c|c|c|c|c|c|c|c|c|c|c|c|c|c|}
\hline \multirow[t]{2}{*}{$\begin{array}{l}\text { Site } \\
\text { num- } \\
\text { ber } \\
\text { (fig. 2) }\end{array}$} & \multirow[t]{2}{*}{ Site name } & \multirow[t]{2}{*}{$\begin{array}{l}\text { USGS or IBWC' } \\
\text { streamflow- } \\
\text { gaging station } \\
\text { number }\end{array}$} & \multirow[t]{2}{*}{$\begin{array}{l}\text { Sub- } \\
\text { reach }^{2} \\
\text { (fig. 2) }\end{array}$} & \multirow[t]{2}{*}{$\begin{array}{l}\text { Sample } \\
\text { date }\end{array}$} & \multirow[t]{2}{*}{$\begin{array}{l}\text { River } \\
\text { mile }\end{array}$} & \multicolumn{2}{|c|}{$\begin{array}{l}\text { Discharge } \\
\qquad\left(\mathrm{ft}^{3} / \mathrm{s}\right)\end{array}$} & \multicolumn{2}{|c|}{$\begin{array}{c}\text { Discharge } \\
\text { measure- } \\
\text { ment } \\
\text { qualifier }\end{array}$} & \multirow[t]{2}{*}{$\mathbf{R P D}^{3}$} & \multirow[t]{2}{*}{$\begin{array}{c}\text { Mean } \\
\text { dis- } \\
\text { charge } \\
\left(\mathrm{ft}^{3} / \mathbf{s}\right)\end{array}$} & \multirow[t]{2}{*}{$\begin{array}{c}\text { Type } \\
\text { of data } \\
\text { collected }\end{array}$} & \multirow[t]{2}{*}{$\begin{array}{l}\text { Latitude } \\
\text { (decimal } \\
\text { degrees) }\end{array}$} & \multirow[t]{2}{*}{$\begin{array}{l}\text { Longi- } \\
\text { tude } \\
\text { (decimal } \\
\text { degrees) }\end{array}$} & \multirow[t]{2}{*}{$\begin{array}{c}\text { Seg- } \\
\text { ment } \\
\text { (fig. 2) }\end{array}$} \\
\hline & & & & & & $\mathbf{n}_{1}$ & $\mathbf{0}_{2}$ & $\mathbf{n}_{1}$ & $\mathbf{0}_{2}$ & & & & & & \\
\hline 35 & $\begin{array}{l}\text { Rio Grande below Foster's Ranch near } \\
\text { Langtry, Tex. }\end{array}$ & 294634101431500 & $\mathrm{E}$ & $2 / 10 / 2006$ & 646.0 & 386 & -- & Good & -- & -- & -- & Q & 29.7761 & 101.7208 & 2305 \\
\hline 36 & $\begin{array}{l}\text { Rio Grande above Rattlesnake Canyon } \\
\text { near Langtry, Tex. }\end{array}$ & 294527101381700 & $\mathrm{E}$ & $2 / 10 / 2006$ & 638.7 & 426 & -- & Fair & -- & -- & -- & Q, QW & 29.7574 & 101.6379 & 2305 \\
\hline 37 & $\begin{array}{l}\text { Rio Grande below Rattlesnake Canyon } \\
\text { near Langtry, Tex. }\end{array}$ & 294615101352800 & $\mathrm{E}$ & $2 / 11 / 2006$ & 635.2 & 406 & -- & Fair & -- & -- & -- & Q & 29.7709 & 101.5910 & 2305 \\
\hline 38 & Rio Grande at take-out near Langtry, Tex. & 294821101330400 & $\mathrm{E}$ & $2 / 11 / 2006$ & 630.8 & 450 & -- & Fair & -- & -- & -- & Q, QW & 29.8058 & 101.5511 & 2305 \\
\hline
\end{tabular}

${ }^{1}$ IBWC streamflow-gaging station with continous streamflow records; continuous records for streamflow used to determine streamflow for sites 1,2, and 34 (discharge measurements made at site 7) (U.S. Geological Survey, 2012); USGS stations are discrete measurement sites.

${ }^{2}$ Subreaches A-E; site 12 is spring site about 0.2 mile upstream from Rio Grande near subreach B.

${ }^{3} \mathrm{RPD}=\left|\mathrm{Q}_{1}-\mathrm{Q}_{2}\right| /\left(\left(\mathrm{Q}_{1}+\mathrm{Q}_{2}\right) / 2\right) \times 100$, where $\mathrm{Q}_{1}$ is the first discharge measurement in replicate pair and $\mathrm{Q}_{2}$ is the second discharge measurement in replicate pair.

${ }^{4}$ Site upstream from Rio Conchos and subreach $\mathrm{A}$.

${ }^{5} \mathrm{Q}$ not used in gain/loss analysis because flow affected by releases from upstream reservoirs. 
Table 2. Criteria and screening levels used to assess surface-water quality in Texas.

[--, not applicable; ${ }^{\circ} \mathrm{C}$, degrees Celsius; $\mathrm{mg} / \mathrm{L}$, milligrams per liter; $\mu \mathrm{g} / \mathrm{L}$, micrograms per liter; TSWQS, Texas Surface Water Quality Standards (Texas Commission on Environmental Quality, 2010)]

\begin{tabular}{|c|c|c|c|c|c|c|}
\hline \multirow{2}{*}{$\begin{array}{l}\text { Constituent } \\
\text { (units) }\end{array}$} & \multicolumn{2}{|c|}{ Aquatic life use protection' } & \multicolumn{2}{|c|}{ Human health criteria ${ }^{2}$} & \multirow{2}{*}{$\begin{array}{c}\text { General use } \\
\text { protection } \\
\text { criteria }^{3}\end{array}$} & \multirow{2}{*}{$\begin{array}{l}\text { Screening } \\
\text { levels }^{4}\end{array}$} \\
\hline & $\begin{array}{l}\text { Acute } \\
\text { criteria }\end{array}$ & $\begin{array}{l}\text { Chronic } \\
\text { criteria }\end{array}$ & $\begin{array}{l}\text { Fish consumption } \\
\text { use }\end{array}$ & $\begin{array}{l}\text { Public water } \\
\text { supply use }\end{array}$ & & \\
\hline $\mathrm{pH}$ (standard units) & -- & -- & -- & -- & $6.5-9.0$ & -- \\
\hline Temperature $\left({ }^{\circ} \mathrm{C}\right)$ & -- & -- & -- & -- & 32.2 & -- \\
\hline Dissloved oxygen $(\mathrm{mg} / \mathrm{L})$ & -- & -- & -- & -- & 5 & -- \\
\hline Chloride $(\mathrm{mg} / \mathrm{L})$ & -- & -- & -- & -- & 300 & -- \\
\hline Sulfate $(\mathrm{mg} / \mathrm{L})$ & -- & -- & -- & -- & 570 & -- \\
\hline Total dissolved solids (mg/L) & -- & -- & -- & -- & 1,500 & -- \\
\hline Ammonia $\left(\mathrm{NH}_{4}\right)(\mathrm{mg} / \mathrm{L})$ & -- & -- & -- & -- & -- & 0.33 \\
\hline Nitrite $\left(\mathrm{NO}_{2}\right)+$ nitrate $\left(\mathrm{NO}_{3}\right)(\mathrm{mg} / \mathrm{L})$ & -- & -- & -- & -- & -- & 2.00 \\
\hline Orthophosphate $\left(\mathrm{PO}_{4}\right)(\mathrm{mg} / \mathrm{L})$ & -- & -- & -- & -- & -- & 0.37 \\
\hline Phosphorus (P) (mg/L) & -- & -- & -- & -- & -- & 0.69 \\
\hline Arsenic $(\mu \mathrm{g} / \mathrm{L})$ & 360 & 190 & -- & 50 & -- & -- \\
\hline Selenium $(\mu \mathrm{g} / \mathrm{L})$ & 20 & 5 & 50 & -- & -- & -- \\
\hline
\end{tabular}

${ }^{1}$ Aquatic life use protection established in the TSWQS includes acute and chronic criteria for metals and organics in water, dissolved oxygen, toxicity in water and sediment, sediment contaminants, biological communities, and in-stream habitat.

${ }^{2}$ Criteria established in the TSWQS designed to prevent contamination of drinking water, fish, and other aquatic life to ensure they are safe for human consumption.

${ }^{3}$ Water-quality criteria established in the TSWQS for segment 2306 to safeguard general water quality, rather than protection of a specific use, except for dissolved-oxygen criterion, which is related to aquatic life use protection.

${ }^{4}$ Statistically derived from 10 years of surface-water-quality monitoring data using the 85th percentile (Lambert and others, 2008, table 3); screening levels used in the absence of established criteria are not criteria but are levels used to denote a concern.

${ }^{5}$ Equivalent to orthophosphorus of TSWQS. 
Table 3. Quality-assurance data for physical properties, major ions, nutrients, and trace elements measured in samples collected from the main-stem Rio Grande, Big Bend area, United States and Mexico, 2006.

[BBNP, Big Bend National Park; WS, surface water; WSQ, quality-control (QC) sample-surface water; OAQ, QC sample-deionized water; --, no data; <, less than; E, estimated]

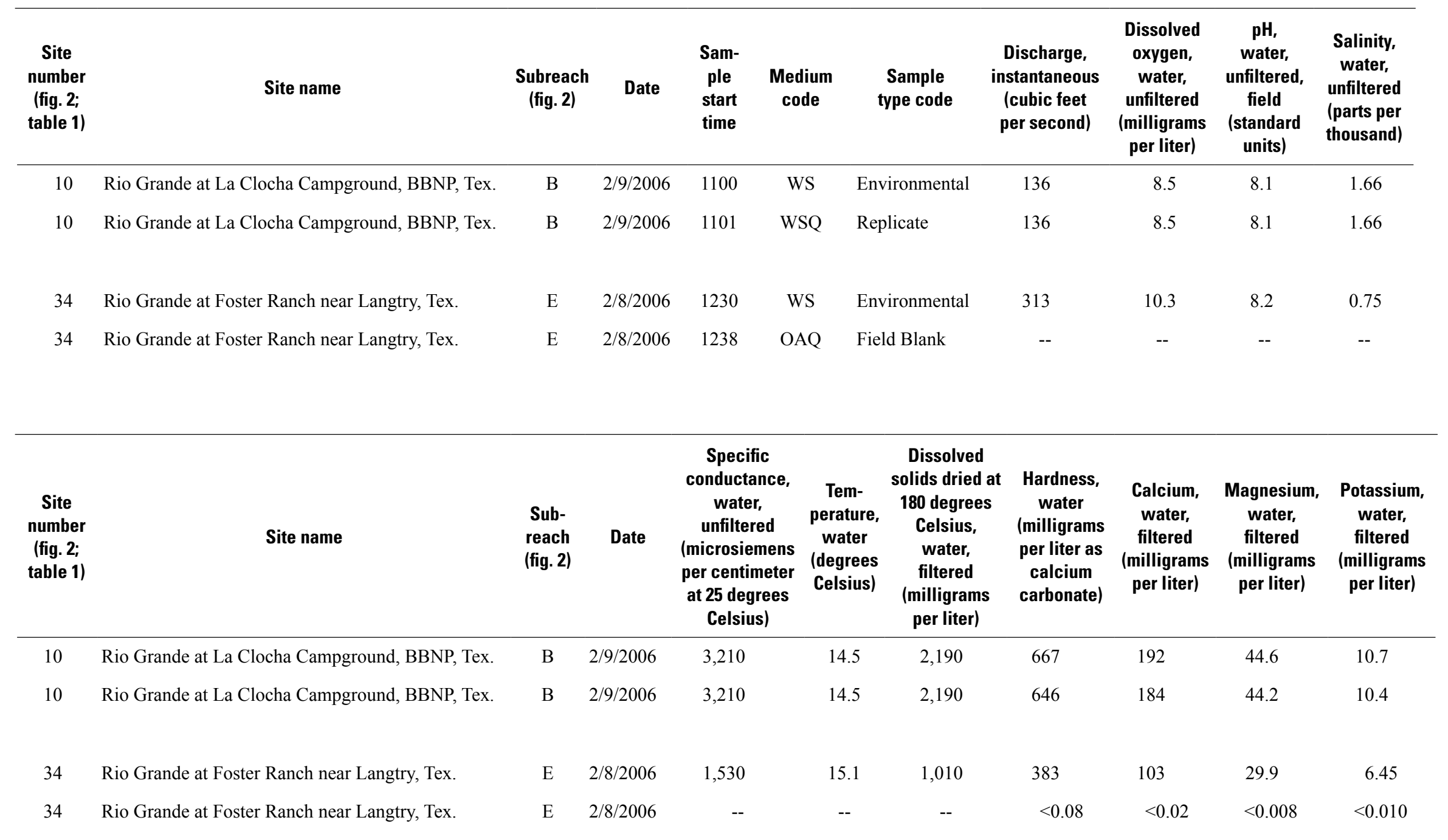


Table 3. Quality-assurance data for physical properties, major ions, nutrients, and trace elements measured in samples collected from the main-stem Rio Grande, Big Bend area, United States and Mexico, 2006.-Continued

[BBNP, Big Bend National Park; WS, surface water; WSQ, quality-control (QC) sample-surface water; OAQ, QC sample-deionized water; --, no data; <, less than; E, estimated]

\begin{tabular}{|c|c|c|c|c|c|c|c|c|c|c|c|c|c|c|}
\hline \multirow[t]{2}{*}{ 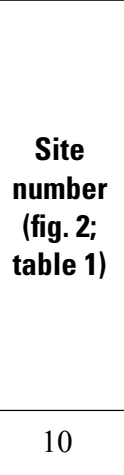 } & Site name & \multirow[t]{2}{*}{$\begin{array}{c}\text { Sub- } \\
\text { reach } \\
\text { (fig. 2) } \\
\\
\text { B }\end{array}$} & \multirow{2}{*}{$\begin{array}{c}\text { Date } \\
2 / 9 / 2006\end{array}$} & \multirow[t]{2}{*}{ 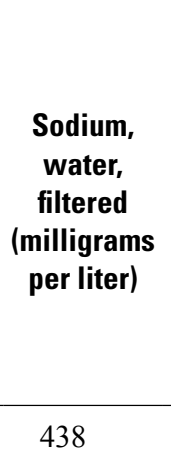 } & $\begin{array}{c}\text { Alkalinity, } \\
\text { water, filtered, } \\
\text { inflection-point } \\
\text { titration method } \\
\text { (incremental } \\
\text { titration } \\
\text { method), field } \\
\text { (milligrams per } \\
\text { liter as calcium } \\
\text { carbonate) }\end{array}$ & \multicolumn{2}{|c|}{$\begin{array}{cc} & \text { Bicarbonate, } \\
\text { water, filtered, } \\
\text { inflection- } \\
\text { it } \\
\text { point titration } \\
\text { method } \\
\text { (incremental } \\
\text { titration } \\
\text { method), field } \\
\text { (milligrams } \\
\text { per liter) }\end{array}$} & \multicolumn{2}{|c|}{$\begin{array}{c}\text { Bromide, } \\
\text { water, } \\
\text { filtered } \\
\text { (milligrams } \\
\text { per liter) }\end{array}$} & \multicolumn{2}{|c|}{$\begin{array}{c}\text { Carbonate, } \\
\text { water, filtered, } \\
\text { inflection-point } \\
\text { titration method } \\
\text { (incremental } \\
\text { titration } \\
\text { method), field } \\
\text { (milligrams } \\
\text { per liter) }\end{array}$} & \multicolumn{2}{|c|}{$\begin{array}{c}\text { Chloride, } \\
\text { water, } \\
\text { filtered } \\
\text { (milligrams } \\
\text { per liter) }\end{array}$} & \multirow[t]{2}{*}{$\begin{array}{c}\begin{array}{c}\text { Fluoride, } \\
\text { water, } \\
\text { filtered } \\
\text { (milligrams } \\
\text { per liter) }\end{array} \\
\\
1.29\end{array}$} \\
\hline & Rio Grande at La Clocha Campground, BBNP, Tex. & & & & 179 & 21 & & 0.8 & & & 1 & 507 & & \\
\hline 10 & Rio Grande at La Clocha Campground, BBNP, Tex. & $\mathrm{B}$ & $2 / 9 / 2006$ & 427 & -- & -- & & 0.6 & & & -- & 507 & & 1.30 \\
\hline 34 & Rio Grande at Foster Ranch near Langtry, Tex. & $\mathrm{E}$ & $2 / 8 / 2006$ & 183 & 174 & 20 & & - & & & 1 & 183 & & 1.19 \\
\hline 34 & Rio Grande at Foster Ranch near Langtry, Tex. & $\mathrm{E}$ & $2 / 8 / 2006$ & $<0.20$ & -- & -- & & - & & & -- & $<0$. & .01 & $<0.01$ \\
\hline $\begin{array}{c}\text { Site } \\
\text { number } \\
\text { (fig. 2; } \\
\text { table 1) }\end{array}$ & Site name & $\begin{array}{l}\text { Sub- } \\
\text { reach } \\
\text { (fig. 2) }\end{array}$ & Date & $\begin{array}{c}\text { Silica, } \\
\text { water, } \\
\text { filtered } \\
\text { (milligrams } \\
\text { per liter } \\
\text { as silicon } \\
\text { dioxide) }\end{array}$ & $\begin{array}{c}\text { Sulfate, } \\
\text { water, } \\
\text { filtered } \\
\text { (milligrams } \\
\text { per liter) }\end{array}$ & $\begin{array}{c}\text { Ammonia } \\
\text { plus organic } \\
\text { nitrogen, } \\
\text { water, } \\
\text { unfiltered } \\
\text { (milligrams } \\
\text { per liter as } \\
\text { nitrogen) }\end{array}$ & $\begin{array}{r}\text { Nitr } \\
\text { plus n } \\
\text { wat } \\
\text { filte } \\
\text { (millig } \\
\text { per lit } \\
\text { nitro }\end{array}$ & $\begin{array}{l}\text { rate } \\
\text { itrite, } \\
\text { ter, } \\
\text { red } \\
\text { grams } \\
\text { ter as } \\
\text { gen) }\end{array}$ & $\begin{array}{r}\text { Nitr } \\
\text { wat } \\
\text { filte } \\
\text { (millig } \\
\text { per lit } \\
\text { nitro }\end{array}$ & $\begin{array}{l}\text { rite, } \\
\text { ter, } \\
\text { red } \\
\text { grams } \\
\text { ter as } \\
\text { gen) }\end{array}$ & $\begin{array}{r}\text { Orthophos } \\
\text { wate } \\
\text { filtere } \\
\text { (milligra } \\
\text { per lite }\end{array}$ & $\begin{array}{l}\text { sphate, } \\
\text { r, } \\
\text { ed } \\
\text { ams } \\
\text { er) }\end{array}$ & $\begin{array}{r}\text { Ortho } \\
\text { (mi } \\
\text { pe } \\
\text { pho }\end{array}$ & $\begin{array}{l}\text { ophosphate, } \\
\text { water, } \\
\text { filtered } \\
\text { nilligrams } \\
\text { er liter as } \\
\text { losphorus) }\end{array}$ \\
\hline 10 & Rio Grande at La Clocha Campground, BBNP, Tex. & $\mathrm{B}$ & $2 / 9 / 2006$ & 14.0 & 746 & -- & $<0.0$ & & $<0$. & 002 & $<0.092$ & & & $<0.030$ \\
\hline 10 & Rio Grande at La Clocha Campground, BBNP, Tex. & $\mathrm{B}$ & $2 / 9 / 2006$ & 13.8 & 748 & -- & $<0.0$ & & E0.C & 001 & $<0.092$ & & & $<0.030$ \\
\hline 34 & Rio Grande at Foster Ranch near Langtry, Tex. & $\mathrm{E}$ & $2 / 8 / 2006$ & 13.5 & 331 & 0.21 & 0.6 & 650 & & 003 & $<0.018$ & & & $<0.006$ \\
\hline 34 & Rio Grande at Foster Ranch near Langtry, Tex. & $\mathrm{E}$ & $2 / 8 / 2006$ & $<0.04$ & $<0.01$ & -- & $<0.0$ & & $<0$. & 002 & $<0.018$ & & & $<0.006$ \\
\hline
\end{tabular}


Table 3. Quality-assurance data for physical properties, major ions, nutrients, and trace elements measured in samples collected from the main-stem Rio Grande, Big Bend area, United States and Mexico, 2006.-Continued

[BBNP, Big Bend National Park; WS, surface water; WSQ, quality-control (QC) sample-surface water; OAQ, QC sample-deionized water; --, no data; <, less than; E, estimated]

\begin{tabular}{|c|c|c|c|c|c|c|c|c|c|c|c|}
\hline $\begin{array}{c}\text { Site } \\
\text { number } \\
\text { (fig. 2; } \\
\text { table 1) }\end{array}$ & Site name & $\begin{array}{l}\text { Sub- } \\
\text { reach } \\
\text { (fig. 2) }\end{array}$ & Date & $\begin{array}{c}\text { Phosphorus, } \\
\text { water, } \\
\text { unfiltered } \\
\text { (milligrams } \\
\text { per liter as } \\
\text { phosphorus) }\end{array}$ & $\begin{array}{c}\text { Iron, } \\
\text { water, } \\
\text { filtered } \\
\text { (micro- } \\
\text { grams } \\
\text { per liter) }\end{array}$ & $\begin{array}{c}\text { Lithium, } \\
\text { water, } \\
\text { filtered } \\
\text { (micro- } \\
\text { grams } \\
\text { per liter) }\end{array}$ & $\begin{array}{c}\text { Strontium, } \\
\text { water, } \\
\text { filtered } \\
\text { (micro- } \\
\text { grams } \\
\text { per liter) }\end{array}$ & $\begin{array}{c}\text { Vanadium, } \\
\text { water, } \\
\text { (filtered } \\
\text { micro- } \\
\text { grams } \\
\text { per liter }\end{array}$ & $\begin{array}{c}\text { Arsenic, } \\
\text { water, } \\
\text { filtered } \\
\text { (micro- } \\
\text { grams } \\
\text { per liter) }\end{array}$ & $\begin{array}{c}\text { Boron, } \\
\text { water, } \\
\text { filtered } \\
\text { (micro- } \\
\text { grams } \\
\text { per liter) }\end{array}$ & $\begin{array}{c}\text { Selenium, } \\
\text { water, } \\
\text { filtered } \\
\text { (micro- } \\
\text { grams } \\
\text { per liter) }\end{array}$ \\
\hline 10 & Rio Grande at La Clocha Campground, BBNP, Tex. & $\mathrm{B}$ & $2 / 9 / 2006$ & -- & E12 & 188 & 3,410 & 2.0 & 3.1 & 469 & 0.62 \\
\hline 10 & Rio Grande at La Clocha Campground, BBNP, Tex. & $\mathrm{B}$ & $2 / 9 / 2006$ & -- & $<18$ & 167 & 3,380 & 2.0 & 3.0 & 497 & 0.61 \\
\hline 34 & Rio Grande at Foster Ranch near Langtry, Tex. & E & $2 / 8 / 2006$ & 0.035 & E5 & 96.2 & 2,170 & 3.5 & 2.6 & 256 & 0.96 \\
\hline 34 & Rio Grande at Foster Ranch near Langtry, Tex. & E & $2 / 8 / 2006$ & -- & $<6$ & $<0.6$ & $<0.40$ & $<0.10$ & $<0.12$ & $<8$ & $<0.08$ \\
\hline
\end{tabular}


Table 4. Streamflow gains and losses computed for sites on the Rio Grande, Big Bend area, United States and Mexico, 2006.

[ $\mathrm{ft}^{3} / \mathrm{s}$, cubic feet per second; --, not calculated; Fair, measured discharge uncertainty 8 percent; Good, measured discharge uncertainty 5 percent]

\begin{tabular}{|c|c|c|c|c|c|c|c|c|c|c|c|}
\hline $\begin{array}{c}\text { Site } \\
\text { number } \\
\text { (fig. 2; } \\
\text { table 1) }\end{array}$ & $\begin{array}{l}\text { Sub- } \\
\text { reach } \\
\text { (fig. 2) }\end{array}$ & $\begin{array}{l}\text { Seg- } \\
\text { ment }\end{array}$ & Date & $\begin{array}{c}\text { Dis- } \\
\text { charge }^{1} \\
\left(\mathrm{ft}^{3} / \mathrm{s}\right)\end{array}$ & $\begin{array}{c}\text { Uncertainty } \\
\text { qualifier }\end{array}$ & $\begin{array}{c}\text { Difference in } \\
\text { streamflow } \\
\text { between } \\
\text { consecutive } \\
\text { downstream and } \\
\text { upstream sites } \\
\text { within subreach } \\
\left(\mathrm{ft}^{3} / \mathrm{s}\right)\end{array}$ & $\begin{array}{c}\text { Potential } \\
\text { measurement } \\
\text { error between } \\
\text { consecutive } \\
\text { downstream and } \\
\text { upstream sites } \\
\left(\mathrm{ft}^{3} / \mathrm{s}\right)\end{array}$ & $\begin{array}{l}\text { Gain, loss, or } \\
\text { no change in } \\
\text { streamflow } \\
\text { (based on } \\
\text { consecutive } \\
\text { downstream } \\
\text { order discharge } \\
\text { measurements) }\end{array}$ & $\begin{array}{l}\text { Difference in } \\
\text { streamflow } \\
\text { between most } \\
\text { downstream and } \\
\text { upstream sites in } \\
\text { subreach } \\
\left(\mathrm{ft}^{3} / \mathrm{s}\right)\end{array}$ & $\begin{array}{c}\text { Potential } \\
\text { measurement } \\
\text { error between } \\
\text { most downstream } \\
\text { and upstream } \\
\text { sites in subreach } \\
\left(\mathrm{ft}^{3} / \mathrm{s}\right)\end{array}$ & $\begin{array}{l}\text { Subreach gain or } \\
\text { loss designation } \\
\text { (based on most } \\
\text { upstream and } \\
\text { downstream } \\
\text { discharge } \\
\text { measurements } \\
\text { in subreach) }\end{array}$ \\
\hline 1 & $\mathrm{U}^{2}$ & 2307 & $6 / 29 / 2006$ & 4.06 & Fair & -- & -- & -- & -- & -- & -- \\
\hline 2 & A & 2306 & $6 / 29 / 2006$ & 41.2 & Fair & -- & -- & -- & -- & -- & -- \\
\hline 3 & A & 2306 & $6 / 20 / 2006$ & 18.7 & Fair & -22.6 & 4.8 & loss & -- & -- & -- \\
\hline 4 & A & 2306 & $6 / 20 / 2006$ & 15.0 & Fair & -3.7 & 2.7 & loss & -26.2 & 4.5 & loss \\
\hline 5 & B & 2306 & $2 / 6 / 2006$ & 114 & Fair & -- & -- & -- & -- & -- & -- \\
\hline 6 & B & 2306 & $2 / 6 / 2006$ & 109 & Fair & -5.0 & 17.8 & no change & -- & -- & -- \\
\hline 7 & B & 2306 & $2 / 7 / 2006$ & 116 & Fair & 6.5 & 18.0 & no change & -- & -- & -- \\
\hline 8 & B & 2306 & $2 / 8 / 2006$ & 121 & Fair & 5.5 & 18.9 & no change & -- & -- & -- \\
\hline 9 & B & 2306 & $2 / 8 / 2006$ & 121 & Fair & 0 & 19.4 & no change & -- & -- & -- \\
\hline 10 & B & 2306 & $2 / 9 / 2006$ & 136 & Fair & 15.0 & 20.6 & no change & -- & -- & -- \\
\hline 11 & B & 2306 & $2 / 10 / 2006$ & 147 & Fair & 11.0 & 22.6 & no change & -- & -- & -- \\
\hline 13 & B & 2306 & $2 / 9 / 2006$ & 153 & Fair & 5.5 & 24.0 & no change & -- & -- & -- \\
\hline 14 & B & 2306 & $2 / 10 / 2006$ & 173 & Fair & 20.5 & 26.0 & no change & 59.0 & 23.0 & gain \\
\hline 15 & $\mathrm{C}$ & 2306 & $6 / 22 / 2006$ & 55.4 & Fair & -- & -- & -- & -- & -- & -- \\
\hline 16 & $\mathrm{C}$ & 2306 & $6 / 22 / 2006$ & 49.0 & Fair & -6.4 & 8.4 & no change & -- & -- & -- \\
\hline 17 & $\mathrm{C}$ & 2306 & $6 / 22 / 2006$ & 92.6 & Fair & 43.6 & 11.3 & gain & 37 & 11.8 & gain \\
\hline 17 & $\mathrm{D}$ & 2306 & $3 / 13 / 2006$ & 162 & Fair & -- & -- & -- & -- & -- & -- \\
\hline 18 & $\mathrm{D}$ & 2306 & $3 / 14 / 2006$ & 183 & Fair & 21.5 & 27.6 & no change & -- & -- & -- \\
\hline 19 & $\mathrm{D}$ & 2306 & $3 / 14 / 2006$ & 183 & Fair & 0 & 29.3 & no change & -- & -- & -- \\
\hline 20 & $\mathrm{D}$ & 2306 & $3 / 15 / 2006$ & 206 & Fair & 23.0 & 31.1 & no change & -- & -- & -- \\
\hline 21 & $\mathrm{D}$ & 2306 & $3 / 15 / 2006$ & 242 & Fair & 36.0 & 35.8 & gain & -- & -- & -- \\
\hline 22 & $\mathrm{D}$ & 2306 & $3 / 15 / 2006$ & 252 & Fair & 10.0 & 39.5 & no change & -- & -- & -- \\
\hline 23 & $\mathrm{D}$ & 2306 & $3 / 16 / 2006$ & 266 & Fair & 14.0 & 41.4 & no change & -- & -- & -- \\
\hline 24 & $\mathrm{D}$ & 2306 & $3 / 16 / 2006$ & 252 & Fair & -14.0 & 41.4 & no change & -- & -- & -- \\
\hline 25 & $\mathrm{D}$ & 2306 & $3 / 17 / 2006$ & 267 & Fair & 15.0 & 41.5 & no change & -- & -- & -- \\
\hline 26 & $\mathrm{D}$ & 2306 & $3 / 18 / 2006$ & 278 & Fair & 11.0 & 43.6 & no change & -- & -- & -- \\
\hline 27 & $\mathrm{D}$ & 2306 & $3 / 19 / 2006$ & ${ }^{3} 445$ & Fair & -- & -- & -- & -- & -- & -- \\
\hline 28 & $\mathrm{D}$ & 2306 & $3 / 20 / 2006$ & ${ }^{3} 393$ & Fair & -- & -- & -- & 116 & 31.5 & gain \\
\hline
\end{tabular}


$\left[\mathrm{ft}^{3} / \mathrm{s}\right.$, cubic feet per second; --, not calculated; Fair, measured discharge uncertainty 8 percent; Good, measured discharge uncertainty 5 percent]

\begin{tabular}{|c|c|c|c|c|c|c|c|c|c|c|c|}
\hline $\begin{array}{c}\text { Site } \\
\text { number } \\
\text { (fig. 2; } \\
\text { table 1) }\end{array}$ & $\begin{array}{l}\text { Sub- } \\
\text { reach } \\
\text { (fig. 2) }\end{array}$ & $\begin{array}{l}\text { Seg- } \\
\text { ment }\end{array}$ & Date & $\begin{array}{c}\text { Dis- } \\
\text { charge }^{1} \\
\left(\mathrm{ft}^{3} / \mathrm{s}\right)\end{array}$ & $\begin{array}{l}\text { Uncertainty } \\
\text { qualifier }\end{array}$ & $\begin{array}{c}\text { Difference in } \\
\text { streamflow } \\
\text { between } \\
\text { consecutive } \\
\text { downstream and } \\
\text { upstream sites } \\
\text { within subreach } \\
\left(\mathrm{ft}^{3} / \mathrm{s}\right)\end{array}$ & $\begin{array}{c}\text { Potential } \\
\text { measurement } \\
\text { error between } \\
\text { consecutive } \\
\text { downstream and } \\
\text { upstream sites } \\
\left(\mathrm{ft}^{3} / \mathrm{s}\right)\end{array}$ & $\begin{array}{l}\text { Gain, loss, or } \\
\text { no change in } \\
\text { streamflow } \\
\text { (based on } \\
\text { consecutive } \\
\text { downstream } \\
\text { order discharge } \\
\text { measurements) }\end{array}$ & $\begin{array}{l}\text { Difference in } \\
\text { streamflow } \\
\text { between most } \\
\text { downstream and } \\
\text { upstream sites in } \\
\text { subreach } \\
\left(\mathrm{ft}^{3} / \mathrm{s}\right)\end{array}$ & $\begin{array}{c}\text { Potential } \\
\text { measurement } \\
\text { error between } \\
\text { most downstream } \\
\text { and upstream } \\
\text { sites in subreach } \\
\left(\mathrm{ft}^{3} / \mathrm{s}\right)\end{array}$ & $\begin{array}{l}\text { Subreach gain or } \\
\text { loss designation } \\
\text { (based on most } \\
\text { upstream and } \\
\text { downstream } \\
\text { discharge } \\
\text { measurements } \\
\text { in subreach) }\end{array}$ \\
\hline 28 & $\mathrm{E}$ & 2306 & $2 / 5 / 2006$ & 292 & Fair & -- & -- & -- & -- & -- & -- \\
\hline 29 & $\mathrm{E}$ & 2306 & $2 / 5 / 2006$ & 338 & Fair & 46.0 & 50.4 & no change & -- & -- & -- \\
\hline 30 & E & 2306 & $2 / 6 / 2006$ & 359 & Fair & 21.0 & 55.8 & no change & -- & -- & -- \\
\hline 31 & $\mathrm{E}$ & 2306 & $2 / 7 / 2006$ & 321 & Fair & -38.0 & 54.4 & no change & -- & -- & -- \\
\hline 32 & $\mathrm{E}$ & 2306 & $2 / 8 / 2006$ & 394 & Fair & 73.0 & 57.2 & gain & -- & -- & -- \\
\hline 33 & $\mathrm{E}$ & 2306 & $2 / 9 / 2006$ & 370 & Fair & -24.0 & 61.1 & no change & -- & -- & -- \\
\hline 34 & $\mathrm{E}$ & 2306 & $2 / 8 / 2006$ & 313 & Fair & -57.0 & 54.6 & loss & -- & -- & -- \\
\hline 35 & $\mathrm{E}$ & 2306 & $2 / 10 / 2006$ & 386 & Good & 73.0 & 44.3 & gain & -- & -- & -- \\
\hline 36 & $\mathrm{E}$ & 2306 & $2 / 10 / 2006$ & 426 & Fair & 40.0 & 53.4 & no change & -- & -- & -- \\
\hline 37 & $\mathrm{E}$ & 2306 & $2 / 11 / 2006$ & 406 & Fair & -20.0 & 66.6 & no change & -- & -- & -- \\
\hline 38 & $\mathrm{E}$ & 2306 & $2 / 11 / 2006$ & 450 & Fair & 44.0 & 68.5 & no change & 158 & 59.4 & gain \\
\hline
\end{tabular}

${ }^{1}$ Mean discharge value used for sites where replicate measurements (table 1) made.

${ }^{2}$ Site upstream from Rio Conchos and subreach A.

${ }^{3}$ Values not used because flow affected by releases from upstream reservoirs. 
Table 5. Selected physical properties and water-quality constituents, including salinity, dissolved solids, and major ions, measured in samples from the main-stem Rio Grande, Big Bend area, United States and Mexico, February 5-June 29, 2006.

[--, no data; E, estimated; <, less than; $\mathrm{SIO}_{2}$, silicon dioxide $]$

\begin{tabular}{|c|c|c|c|c|c|c|c|c|c|c|}
\hline $\begin{array}{c}\text { Site } \\
\text { number } \\
\text { (fig. 2; } \\
\text { table 1) }\end{array}$ & $\begin{array}{l}\text { Sub- } \\
\text { reach } \\
\text { (fig. 2) }\end{array}$ & Site name & Date & $\begin{array}{l}\text { Sam- } \\
\text { ple } \\
\text { start } \\
\text { time }\end{array}$ & $\begin{array}{c}\text { Dissolved } \\
\text { oxygen, } \\
\text { water, } \\
\text { unfiltered } \\
\text { (milligrams } \\
\text { per liter) }\end{array}$ & $\begin{array}{c}\text { pH, } \\
\text { water, } \\
\text { unfiltered, } \\
\text { field } \\
\text { (standard } \\
\text { units) }\end{array}$ & $\begin{array}{c}\text { Salinity, } \\
\text { water, } \\
\text { unfiltered } \\
\text { (parts per } \\
\text { thousand') }\end{array}$ & $\begin{array}{c}\text { Specific } \\
\text { conductance, } \\
\text { water, unfiltered } \\
\text { (microsiemens } \\
\text { per centimeter } \\
\text { at } 25 \text { degrees } \\
\text { Celsius) }\end{array}$ & $\begin{array}{c}\text { Tempera- } \\
\text { ture, } \\
\text { water } \\
\text { (degrees } \\
\text { Celsius) }\end{array}$ & $\begin{array}{c}\text { Dissolved solids } \\
\text { dried at } 180 \text { de- } \\
\text { grees Celsius, } \\
\text { water, filtered } \\
\text { (milligrams } \\
\text { per liter) }\end{array}$ \\
\hline 1 & $\mathrm{U}^{2}$ & Rio Grande above Rio Conchos near Presidio, Tex. & $6 / 29 / 2006$ & 0930 & 6.8 & 8.0 & 1.01 & 2,020 & 22.9 & 1,460 \\
\hline 2 & A & Rio Grande below Rio Conchos near Presidio, Tex. & $6 / 29 / 2006$ & 1430 & 8.4 & 7.9 & 1.71 & 3,300 & 28.8 & 2,460 \\
\hline 3 & A & Rio Grande at Rancherias Rapids near Redford, Tex. & $6 / 20 / 2006$ & 1200 & 7.7 & 7.9 & 1.76 & 3,400 & 28.5 & 2560 \\
\hline 4 & A & Rio Grande above Lajitas, Tex. & $6 / 20 / 2006$ & 1500 & 8.1 & 8.0 & 1.68 & 3,250 & 33.0 & 2,420 \\
\hline 5 & $\mathrm{~B}$ & Rio Grande at Santa Elena Canyon, BBNP, Tex. & $2 / 6 / 2006$ & 1200 & 10.2 & 8.3 & 1.78 & 3,430 & 12.1 & 2,320 \\
\hline 6 & $\mathrm{~B}$ & Rio Grande near Castolon, Tex. & $2 / 6 / 2006$ & 1530 & 11.3 & 8.4 & 1.78 & 3,420 & 15.4 & 2,290 \\
\hline 7 & $\mathrm{~B}$ & Rio Grande at Johnson Ranch near Castolon, Tex. & $2 / 7 / 2006$ & 1430 & 10.5 & 8.3 & 1.80 & 3,470 & 13.0 & 2,340 \\
\hline 8 & $\mathrm{~B}$ & Rio Grande at Talley Campground, BBNP, Tex. & $2 / 8 / 2006$ & 1130 & 7.4 & 8.2 & 1.82 & 3,510 & 12.9 & 2,390 \\
\hline 10 & B & Rio Grande at La Clocha Campground, BBNP, Tex. & $2 / 9 / 2006$ & 1100 & 8.5 & 8.1 & 1.66 & 3,210 & 14.5 & 2,190 \\
\hline 13 & $\mathrm{~B}$ & Rio Grande at Rio Grande Village, BBNP, Tex. & $2 / 9 / 2006$ & 1400 & 7.5 & 7.9 & 1.17 & 2,930 & 19.6 & 1,990 \\
\hline 15 & $\mathrm{C}$ & Rio Grande at La Linda, Mexico & $6 / 22 / 2006$ & 1115 & 8.1 & 8.3 & 0.70 & 1,440 & 30.0 & 1,020 \\
\hline 17 & $\mathrm{D}$ & Rio Grande at Taylor's Farm near Sanderson, Tex. & $3 / 13 / 2006$ & 1500 & 9.9 & 8.0 & 0.98 & 1,970 & 21.3 & 1,280 \\
\hline 20 & $\mathrm{D}$ & Rio Grande above Silber Canyon near Sanderson, Tex. & $3 / 15 / 2006$ & 1030 & 9.0 & 8.1 & 0.88 & 1,770 & 18.9 & 1,160 \\
\hline 24 & $\mathrm{D}$ & Rio Grande below Rodeo Rapids near Sanderson, Tex. & $3 / 16 / 2006$ & 1630 & 9.8 & 8.2 & 0.76 & 1,550 & 23.7 & 993 \\
\hline 26 & $\mathrm{D}$ & Rio Grande below Panther Gulch near Sanderson, Tex. & $3 / 18 / 2006$ & 1100 & 8.5 & 8.1 & 0.70 & 1,430 & 23.0 & 932 \\
\hline 29 & $\mathrm{E}$ & Rio Grande above Shafter Crossing near Dryden, Tex. & $2 / 5 / 2006$ & 1815 & 9.6 & 8.2 & 0.82 & 1,660 & 17.0 & 1,080 \\
\hline 32 & $\mathrm{E}$ & Rio Grande above Lozier Canyon near Dryden, Tex. & $2 / 8 / 2006$ & 1145 & 10.0 & 8.3 & 0.77 & 1,560 & 15.1 & 1,020 \\
\hline 34 & $\mathrm{E}$ & Rio Grande at Foster Ranch near Langtry, Tex. & $2 / 8 / 2006$ & 1230 & 10.3 & 8.2 & 0.75 & 1,530 & 15.1 & 1,010 \\
\hline 36 & E & Rio Grande above Rattlesnake Canyon near Langtry, Tex. & $2 / 10 / 2006$ & 1700 & 10.3 & 8.3 & 0.69 & 1,420 & 15.3 & 917 \\
\hline 38 & $\mathrm{E}$ & Rio Grande at take-out near Langtry, Tex. & $2 / 11 / 2006$ & 1730 & 10.5 & 8.3 & 0.67 & 1,380 & 15.6 & 886 \\
\hline
\end{tabular}


Table 5. Selected physical properties and water-quality constituents, including salinity, dissolved solids, and major ions, measured in samples from the main-stem Rio Grande, Big Bend area, United States and Mexico, February 5-June 29, 2006.-Continued

$\begin{array}{cc}\begin{array}{c}\text { Site } \\ \text { number }\end{array} & \begin{array}{c}\text { Sub- } \\ \text { (fig. 2; }\end{array} \\ \text { reach } \\ \text { table 1) } & \text { (fig. 2) }\end{array}$

Site name
Date

Hardness,

water Calcium

(milli-

grams

per liter as

calcium

carbonate)

filtered

per liter)

Alkalinity

water, filtered

Bicarbonate,

inflection-

water,

filtered,

$\begin{array}{ccc}\text { Calcium, nesium, } & \begin{array}{c}\text { Potassium, } \\ \text { water, }\end{array} & \begin{array}{c}\text { Sodium, } \\ \text { water, }\end{array}\end{array}$

filtered

filtered

method

inflection-

point titration

(milligrams filtered (milligrams (milligrams

titration

per liter)

per liter)

per liter)

method), field

method

method), field

per liter as (milligrams

calcium

milligrams

carbonate)

\begin{tabular}{|c|c|c|c|c|c|c|c|c|c|c|}
\hline 1 & $\mathrm{U}^{2}$ & Rio Grande above Rio Conchos near Presidio, Tex. & $6 / 29 / 2006$ & 452 & 144 & 22.1 & 8.70 & 244 & -- & -- \\
\hline 2 & A & Rio Grande below Rio Conchos near Presidio, Tex. & $6 / 29 / 2006$ & 809 & 256 & 39.9 & 10.3 & 411 & 249 & 299 \\
\hline 3 & A & Rio Grande at Rancherias Rapids near Redford, Tex. & $6 / 20 / 2006$ & 664 & 203 & 37.1 & 9.51 & 473 & -- & -- \\
\hline 4 & A & Rio Grande above Lajitas, Tex. & $6 / 20 / 2006$ & 722 & 216 & 43.1 & 12.6 & 470 & -- & -- \\
\hline 5 & $\mathrm{~B}$ & Rio Grande at Santa Elena Canyon, BBNP, Tex. & $2 / 6 / 2006$ & 678 & 196 & 44.7 & 11.5 & 501 & 201 & 240 \\
\hline 6 & $\mathrm{~B}$ & Rio Grande near Castolon, Tex. & $2 / 6 / 2006$ & 664 & 190 & 45.3 & 11.5 & 507 & 184 & E220 \\
\hline 7 & $\mathrm{~B}$ & Rio Grande at Johnson Ranch near Castolon, Tex. & $2 / 7 / 2006$ & 678 & 194 & 46.0 & 11.0 & 489 & 190 & 225 \\
\hline 8 & $\mathrm{~B}$ & Rio Grande at Talley Campground, BBNP, Tex. & $2 / 8 / 2006$ & 694 & 199 & 46.6 & 11.5 & 492 & 172 & 208 \\
\hline 10 & $\mathrm{~B}$ & Rio Grande at La Clocha Campground, BBNP, Tex. & $2 / 9 / 2006$ & 667 & 192 & 44.6 & 10.7 & 438 & 179 & 216 \\
\hline 13 & $\mathrm{~B}$ & Rio Grande at Rio Grande Village, BBNP, Tex. & $2 / 9 / 2006$ & 617 & 175 & 43.0 & 9.73 & 378 & 183 & 220 \\
\hline 15 & $\mathrm{C}$ & Rio Grande at La Linda, Mexico & $6 / 22 / 2006$ & 415 & 110 & 33.0 & 7.29 & 153 & -- & -- \\
\hline 17 & $\mathrm{D}$ & Rio Grande at Taylor's Farm near Sanderson, Tex. & $3 / 13 / 2006$ & 458 & 126 & 34.0 & 7.87 & 239 & 176 & 212 \\
\hline 20 & $\mathrm{D}$ & Rio Grande above Silber Canyon near Sanderson, Tex. & $3 / 15 / 2006$ & 413 & 111 & 32.2 & 7.49 & 210 & 158 & 191 \\
\hline 24 & $\mathrm{D}$ & Rio Grande below Rodeo Rapids near Sanderson, Tex. & $3 / 16 / 2006$ & 376 & 101 & 29.6 & 6.63 & 174 & 168 & 201 \\
\hline 26 & $\mathrm{D}$ & Rio Grande below Panther Gulch near Sanderson, Tex. & $3 / 18 / 2006$ & 356 & 94.2 & 28.5 & 6.20 & 162 & 163 & 195 \\
\hline 29 & $\mathrm{E}$ & Rio Grande above Shafter Crossing near Dryden, Tex. & $2 / 5 / 2006$ & 372 & 99.9 & 29.0 & 6.43 & 190 & 170 & 203 \\
\hline 32 & $\mathrm{E}$ & Rio Grande above Lozier Canyon near Dryden, Tex. & $2 / 8 / 2006$ & 365 & 98.5 & 28.1 & 6.06 & 178 & 174 & 208 \\
\hline 34 & $\mathrm{E}$ & Rio Grande at Foster Ranch near Langtry, Tex. & $2 / 8 / 2006$ & 383 & 103 & 29.9 & 6.45 & 183 & 174 & 209 \\
\hline 36 & $\mathrm{E}$ & Rio Grande above Rattlesnake Canyon near Langtry, Tex. & $2 / 10 / 2006$ & 351 & 94.3 & 27.4 & 5.75 & 161 & 167 & 199 \\
\hline 38 & $\mathrm{E}$ & Rio Grande at take-out near Langtry, Tex. & $2 / 11 / 2006$ & 336 & 90.4 & 26.3 & 5.38 & 151 & 174 & 208 \\
\hline
\end{tabular}


Table 5. Selected physical properties and water-quality constituents, including salinity, dissolved solids, and major ions, measured in samples from the main-stem Rio Grande, Big Bend area, United States and Mexico, February 5-June 29, 2006.-Continued

[--, no data; E, estimated; <, less than; $\mathrm{SIO}_{2}$, silicon dioxide $]$

\begin{tabular}{|c|c|c|c|c|c|c|c|c|c|}
\hline $\begin{array}{c}\text { Site } \\
\text { number } \\
\text { (fig. 2; } \\
\text { table 1) }\end{array}$ & $\begin{array}{c}\text { Subreach } \\
\text { (fig. 2) }\end{array}$ & Site name & Date & $\begin{array}{c}\text { Bromide, } \\
\text { water, } \\
\text { filtered } \\
\text { (milligrams } \\
\text { per liter) }\end{array}$ & $\begin{array}{l}\text { Carbonate, water, filtered, } \\
\text { inflection-point titration } \\
\text { method (incremental } \\
\text { titration method), field } \\
\text { (milligrams } \\
\text { per liter) }\end{array}$ & $\begin{array}{l}\text { Chloride, } \\
\text { water, } \\
\text { filtered } \\
\text { (milligrams } \\
\text { per liter) }\end{array}$ & $\begin{array}{c}\text { Fluoride, } \\
\text { water, } \\
\text { filtered } \\
\text { (milligrams } \\
\text { per liter) }\end{array}$ & $\begin{array}{l}\text { Silica, } \\
\text { water, } \\
\text { filtered } \\
\text { (milligrams } \\
\text { per liter } \\
\text { as } \mathrm{SiO}_{2} \text { ) }\end{array}$ & $\begin{array}{c}\text { Sulfate, } \\
\text { water, } \\
\text { filtered } \\
\text { (milligrams } \\
\text { per liter) }\end{array}$ \\
\hline 1 & $\mathrm{U}^{2}$ & Rio Grande above Rio Conchos near Presidio, Tex. & $6 / 29 / 2006$ & 0.51 & -- & 153 & 2.00 & 21.6 & 661 \\
\hline 2 & A & Rio Grande below Rio Conchos near Presidio, Tex. & $6 / 29 / 2006$ & 0.75 & 2 & 320 & 1.65 & 26.1 & 1,060 \\
\hline 3 & A & Rio Grande at Rancherias Rapids near Redford, Tex. & $6 / 20 / 2006$ & 0.83 & -- & 424 & 1.60 & 22.8 & 1050 \\
\hline 4 & A & Rio Grande above Lajitas, Tex. & $6 / 20 / 2006$ & 0.83 & -- & 391 & 1.71 & 26.8 & 1,030 \\
\hline 5 & $\mathrm{~B}$ & Rio Grande at Santa Elena Canyon, BBNP, Tex. & $2 / 6 / 2006$ & 0.84 & 2 & 580 & 1.20 & 11.8 & 754 \\
\hline 6 & $\mathrm{~B}$ & Rio Grande near Castolon, Tex. & $2 / 6 / 2006$ & 0.87 & E2 & 574 & 1.22 & 12.0 & 752 \\
\hline 7 & $\mathrm{~B}$ & Rio Grande at Johnson Ranch near Castolon, Tex. & $2 / 7 / 2006$ & 0.82 & 3 & 582 & 1.22 & 12.7 & 761 \\
\hline 8 & $\mathrm{~B}$ & Rio Grande at Talley Campground, BBNP, Tex. & $2 / 8 / 2006$ & 0.79 & 1 & 592 & 1.19 & 12.9 & 783 \\
\hline 10 & $\mathrm{~B}$ & Rio Grande at La Clocha Campground, BBNP, Tex. & $2 / 9 / 2006$ & 0.82 & 1 & 507 & 1.29 & 14.0 & 746 \\
\hline 13 & $\mathrm{~B}$ & Rio Grande at Rio Grande Village, BBNP, Tex. & 2/9/2006 & 0.81 & 1 & 441 & 1.41 & 15.7 & 689 \\
\hline 15 & $\mathrm{C}$ & Rio Grande at La Linda, Mexico & $6 / 22 / 2006$ & 0.39 & -- & 117 & 1.84 & 24.4 & 454 \\
\hline 17 & $\mathrm{D}$ & Rio Grande at Taylor's Farm near Sanderson, Tex. & $3 / 13 / 2006$ & 0.45 & $<1$ & 236 & 1.48 & 20.1 & 448 \\
\hline 20 & $\mathrm{D}$ & Rio Grande above Silber Canyon near Sanderson, Tex. & $3 / 15 / 2006$ & 0.43 & 1 & 205 & 1.46 & 19.9 & 396 \\
\hline 24 & $\mathrm{D}$ & Rio Grande below Rodeo Rapids near Sanderson, Tex. & $3 / 16 / 2006$ & 0.36 & 2 & 170 & 1.47 & 19.2 & 331 \\
\hline 26 & $\mathrm{D}$ & Rio Grande below Panther Gulch near Sanderson, Tex. & $3 / 18 / 2006$ & 0.33 & 2 & 157 & 1.38 & 18.6 & 307 \\
\hline 29 & $\mathrm{E}$ & Rio Grande above Shafter Crossing near Dryden, Tex. & $2 / 5 / 2006$ & 0.40 & 2 & 203 & 1.27 & 13.5 & 368 \\
\hline 32 & $\mathrm{E}$ & Rio Grande above Lozier Canyon near Dryden, Tex. & $2 / 8 / 2006$ & 0.37 & 2 & 188 & 1.21 & 13.7 & 335 \\
\hline 34 & $\mathrm{E}$ & Rio Grande at Foster Ranch near Langtry, Tex. & $2 / 8 / 2006$ & -- & 1 & 183 & 1.19 & 13.5 & 331 \\
\hline 36 & $\mathrm{E}$ & Rio Grande above Rattlesnake Canyon near Langtry, Tex. & $2 / 10 / 2006$ & 0.34 & 2 & 167 & 1.13 & 14.6 & 296 \\
\hline 38 & E & Rio Grande at take-out near Langtry, Tex. & $2 / 11 / 2006$ & 0.33 & 2 & 161 & 1.11 & 15.1 & 282 \\
\hline
\end{tabular}

'Estimated from 30-point rating table (Wagner and others, 2000) using specific conductance measured at site.

${ }^{2}$ Site upstream from Rio Conchos and subreach A. 


\begin{tabular}{|c|c|c|c|c|c|c|c|c|c|c|c|}
\hline $\begin{array}{c}\text { Site } \\
\text { number } \\
\text { (fig. 2; } \\
\text { table 1) }\end{array}$ & $\begin{array}{c}\text { Sub- } \\
\text { reach } \\
\text { (fig. 2) }\end{array}$ & Site name & Date & $\begin{array}{c}\text { Sample } \\
\text { start } \\
\text { time }\end{array}$ & $\begin{array}{l}\text { Medium } \\
\text { code }\end{array}$ & $\begin{array}{c}\text { Ammonia } \\
\text { plus organic } \\
\text { nitrogen, } \\
\text { water, } \\
\text { unfiltered } \\
\text { (milligrams } \\
\text { per liter as } \\
\text { nitrogen) }\end{array}$ & $\begin{array}{c}\text { Nitrate } \\
\text { plus nitrite, } \\
\text { water, } \\
\text { filtered } \\
\text { (milligrams } \\
\text { per liter as } \\
\text { nitrogen) }\end{array}$ & $\begin{array}{c}\text { Nitrite, } \\
\text { water, } \\
\text { filtered } \\
\text { (milligrams } \\
\text { per liter as } \\
\text { nitrogen) }\end{array}$ & $\begin{array}{c}\text { Ortho- } \\
\text { phosphate, } \\
\text { water, } \\
\text { filtered } \\
\text { (milligrams } \\
\text { per liter) }\end{array}$ & $\begin{array}{c}\text { Ortho- } \\
\text { phosphate, } \\
\text { water, } \\
\text { filtered } \\
\text { (milligrams } \\
\text { per liter } \\
\text { as phos- } \\
\text { phorus) }\end{array}$ & $\begin{array}{c}\text { Phospho- } \\
\text { rus, water, } \\
\text { unfiltered } \\
\text { (milligrams } \\
\text { per liter as } \\
\text { phosphorus) }\end{array}$ \\
\hline 1 & $\mathrm{U}^{1}$ & Rio Grande above Rio Conchos near Presidio, Tex. & $6 / 29 / 2006$ & 0930 & WS & -- & 0.283 & 0.011 & 0.024 & 0.008 & -- \\
\hline 2 & A & Rio Grande below Rio Conchos near Presidio, Tex. & $6 / 29 / 2006$ & 1430 & WS & 0.60 & 0.41 & 0.013 & 0.03 & 0.01 & 0.12 \\
\hline 3 & A & Rio Grande at Rancherias Rapids near Redford, Tex. & $6 / 20 / 2006$ & 1200 & WS & -- & 0.028 & 0.002 & 0.026 & 0.009 & -- \\
\hline 4 & A & Rio Grande above Lajitas, Tex. & $6 / 20 / 2006$ & 1500 & WS & -- & $<0.016$ & $<0.002$ & 0.029 & 0.009 & -- \\
\hline 5 & $\mathrm{~B}$ & Rio Grande at Santa Elena Canyon, BBNP, Tex. & $2 / 6 / 2006$ & 1200 & WS & -- & $<0.016$ & $<0.002$ & $<0.092$ & $<0.030$ & -- \\
\hline 6 & $\mathrm{~B}$ & Rio Grande near Castolon, Tex. & $2 / 6 / 2006$ & 1530 & WS & -- & $<0.016$ & $<0.002$ & $<0.092$ & $<0.030$ & -- \\
\hline 7 & $\mathrm{~B}$ & Rio Grande at Johnson Ranch near Castolon, Tex. & $2 / 7 / 2006$ & 1430 & WS & -- & $<0.016$ & $<0.002$ & $<0.092$ & $<0.030$ & -- \\
\hline 8 & $\mathrm{~B}$ & Rio Grande at Talley Campground, BBNP, Tex. & $2 / 8 / 2006$ & 1130 & WS & -- & $<0.016$ & $<0.002$ & $<0.092$ & $<0.030$ & -- \\
\hline 10 & $\mathrm{~B}$ & Rio Grande at La Clocha Campground, BBNP, Tex. & 2/9/2006 & 1100 & WS & -- & $<0.016$ & $<0.002$ & $<0.092$ & $<0.030$ & -- \\
\hline 13 & $\mathrm{~B}$ & Rio Grande at Rio Grande Village, BBNP, Tex. & 2/9/2006 & 1400 & WS & -- & $<0.016$ & E0.001 & $<0.092$ & $<0.030$ & -- \\
\hline 15 & $\mathrm{C}$ & Rio Grande at La Linda, Mexico & $6 / 22 / 2006$ & 1115 & WS & -- & E0.011 & $<0.002$ & 0.023 & 0.008 & -- \\
\hline 17 & $\mathrm{D}$ & Rio Grande at Taylor's Farm near Sanderson, Tex. & $3 / 13 / 2006$ & 1500 & WS & -- & 0.293 & 0.004 & $<0.055$ & $<0.02$ & -- \\
\hline 20 & $\mathrm{D}$ & Rio Grande above Silber Canyon near Sanderson, Tex. & $3 / 15 / 2006$ & 1030 & WS & -- & 0.331 & 0.004 & $<0.055$ & $<0.02$ & -- \\
\hline 24 & $\mathrm{D}$ & Rio Grande below Rodeo Rapids near Sanderson, Tex. & $3 / 16 / 2006$ & 1630 & WS & -- & 0.541 & 0.004 & $<0.055$ & $<0.02$ & -- \\
\hline 26 & $\mathrm{D}$ & Rio Grande below Panther Gulch near Sanderson, Tex. & $3 / 18 / 2006$ & 1100 & WS & -- & 0.642 & 0.004 & $<0.055$ & $<0.02$ & -- \\
\hline 29 & $\mathrm{E}$ & Rio Grande above Shafter Crossing near Dryden, Tex. & $2 / 5 / 2006$ & 1815 & WS & -- & 0.593 & 0.003 & $<0.018$ & $<0.006$ & -- \\
\hline 32 & $\mathrm{E}$ & Rio Grande above Lozier Canyon near Dryden, Tex. & $2 / 8 / 2006$ & 1145 & WS & -- & 0.66 & 0.003 & $<0.092$ & $<0.030$ & -- \\
\hline 34 & $\mathrm{E}$ & Rio Grande at Foster Ranch near Langtry, Tex. & $2 / 8 / 2006$ & 1230 & WS & 0.21 & 0.65 & 0.003 & $<0.018$ & $<0.006$ & 0.035 \\
\hline 36 & $\mathrm{E}$ & Rio Grande above Rattlesnake Canyon near Langtry, Tex. & $2 / 10 / 2006$ & 1700 & WS & -- & 0.748 & 0.003 & $<0.092$ & $<0.030$ & -- \\
\hline 38 & $\mathrm{E}$ & Rio Grande at take-out near Langtry, Tex. & $2 / 11 / 2006$ & 1730 & WS & -- & 0.818 & 0.004 & $<0.092$ & $<0.030$ & -- \\
\hline
\end{tabular}


Table 7. Trace-element data in water-quality samples from the main-stem Rio Grande, Big Bend area, United States and Mexico, February 5-June 29, 2006.

[WS, surface water; <, less than; BBNP, Big Bend National Park; E, estimated]

\begin{tabular}{|c|c|c|c|c|c|c|c|c|c|c|c|c|}
\hline $\begin{array}{c}\text { Site } \\
\text { number } \\
\text { (fig. 2; } \\
\text { table 1) }\end{array}$ & $\begin{array}{l}\text { Sub- } \\
\text { reach } \\
\text { (fig. 2) }\end{array}$ & Site name & Date & $\begin{array}{l}\text { Sam- } \\
\text { ple } \\
\text { start } \\
\text { time }\end{array}$ & $\begin{array}{l}\text { Medium } \\
\text { code }\end{array}$ & $\begin{array}{c}\text { Iron, } \\
\text { water, } \\
\text { filtered } \\
\text { micro- } \\
\text { grams } \\
\text { per liter) }\end{array}$ & $\begin{array}{c}\text { Arsenic, } \\
\text { water, } \\
\text { filtered } \\
\text { (micro- } \\
\text { grams } \\
\text { per liter) }\end{array}$ & $\begin{array}{c}\text { Boron, } \\
\text { water, } \\
\text { filtered } \\
\text { (micro- } \\
\text { grams } \\
\text { per liter) }\end{array}$ & $\begin{array}{c}\text { Lithium, } \\
\text { water, } \\
\text { filtered } \\
\text { (micro- } \\
\text { grams } \\
\text { per liter) }\end{array}$ & $\begin{array}{c}\text { Selenium, } \\
\text { water, } \\
\text { filtered } \\
\text { (micro- } \\
\text { grams } \\
\text { per liter) }\end{array}$ & $\begin{array}{c}\text { Stron- } \\
\text { tium, } \\
\text { water, } \\
\text { filtered } \\
\text { (micro- } \\
\text { grams } \\
\text { per liter) }\end{array}$ & $\begin{array}{c}\text { Vana- } \\
\text { dium, } \\
\text { water, } \\
\text { filtered } \\
\text { (micro- } \\
\text { grams } \\
\text { per liter) }\end{array}$ \\
\hline 1 & $\mathrm{U}^{1}$ & Rio Grande above Rio Conchos near Presidio, Tex. & $6 / 29 / 2006$ & 0930 & WS & $<6$ & 4.5 & 438 & 117 & 1.2 & 2,710 & 4.2 \\
\hline 2 & A & Rio Grande below Rio Conchos near Presidio, Tex. & $6 / 29 / 2006$ & 1430 & WS & $<18$ & 2.8 & 607 & 150 & 1.6 & 3,690 & 3.4 \\
\hline 3 & A & Rio Grande at Rancherias Rapids near Redford, Tex. & $6 / 20 / 2006$ & 1200 & WS & $<18$ & 2.2 & 501 & 74.3 & 0.66 & 3,540 & 1.8 \\
\hline 4 & A & Rio Grande above Lajitas, Tex. & $6 / 20 / 2006$ & 1500 & WS & $<18$ & 2.8 & 508 & 77.9 & 0.50 & 3,530 & 2.5 \\
\hline 5 & $\mathrm{~B}$ & Rio Grande at Santa Elena Canyon, BBNP, Tex. & $2 / 6 / 2006$ & 1200 & WS & E17 & 3.4 & 476 & 201 & 0.61 & 3,240 & 2.1 \\
\hline 6 & $\mathrm{~B}$ & Rio Grande near Castolon, Tex. & $2 / 6 / 2006$ & 1530 & WS & $<18$ & 3.3 & 522 & 186 & 0.62 & 3,120 & 2.0 \\
\hline 7 & $\mathrm{~B}$ & Rio Grande at Johnson Ranch near Castolon, Tex. & $2 / 7 / 2006$ & 1430 & WS & E13 & 3.1 & 511 & 178 & 0.60 & 3,200 & 1.8 \\
\hline 8 & $\mathrm{~B}$ & Rio Grande at Talley Campground, BBNP, Tex. & $2 / 8 / 2006$ & 1130 & WS & E16 & 3.0 & 480 & 200 & 0.52 & 3,360 & 1.9 \\
\hline 10 & B & Rio Grande at La Clocha Campground, BBNP, Tex. & $2 / 9 / 2006$ & 1100 & WS & E12 & 3.1 & 469 & 188 & 0.62 & 3,410 & 2.0 \\
\hline 13 & $\mathrm{~B}$ & Rio Grande at Rio Grande Village, BBNP, Tex. & $2 / 9 / 2006$ & 1400 & WS & E18 & 3.4 & 462 & 160 & 0.67 & 3,450 & 2.1 \\
\hline 15 & $\mathrm{C}$ & Rio Grande at La Linda, Mexico & $6 / 22 / 2006$ & 1115 & WS & $<6$ & 4.3 & 325 & 118 & 1.4 & 3,400 & 4.4 \\
\hline 17 & $\mathrm{D}$ & Rio Grande at Taylor's Farm near Sanderson, Tex. & $3 / 13 / 2006$ & 1500 & WS & $<6$ & 3.5 & 366 & 116 & 1.0 & 2,890 & 3.8 \\
\hline 20 & $\mathrm{D}$ & Rio Grande above Silber Canyon near Sanderson, Tex. & $3 / 15 / 2006$ & 1030 & WS & $<6$ & 3.4 & 343 & 113 & 1.0 & 2,700 & 3.8 \\
\hline 24 & $\mathrm{D}$ & Rio Grande below Rodeo Rapids near Sanderson, Tex. & $3 / 16 / 2006$ & 1630 & WS & $<6$ & 3.3 & 252 & 99.6 & 1.2 & 2,330 & 4.1 \\
\hline 26 & $\mathrm{D}$ & Rio Grande below Panther Gulch near Sanderson, Tex. & $3 / 18 / 2006$ & 1100 & WS & $<6$ & 3.2 & 314 & 132 & 1.1 & 2,340 & 4.3 \\
\hline 29 & $\mathrm{E}$ & Rio Grande above Shafter Crossing near Dryden, Tex. & $2 / 5 / 2006$ & 1815 & WS & $<6$ & 2.6 & 273 & 101 & 1.0 & 2,430 & 3.3 \\
\hline 32 & $\mathrm{E}$ & Rio Grande above Lozier Canyon near Dryden, Tex. & $2 / 8 / 2006$ & 1145 & WS & $<6$ & 2.4 & 256 & 96.2 & 1.0 & 2,320 & 3.5 \\
\hline 34 & $\mathrm{E}$ & Rio Grande at Foster Ranch near Langtry, Tex. & $2 / 8 / 2006$ & 1230 & WS & E5 & 2.6 & 256 & 96.2 & 0.96 & 2,170 & 3.5 \\
\hline 36 & $\mathrm{E}$ & Rio Grande above Rattlesnake Canyon near Langtry, Tex. & $2 / 10 / 2006$ & 1700 & WS & $<6$ & 2.4 & 229 & 84.8 & 1.0 & 2,040 & 3.8 \\
\hline 38 & $\mathrm{E}$ & Rio Grande at take-out near Langtry, Tex. & $2 / 11 / 2006$ & 1730 & WS & $<6$ & 2.2 & 220 & 79.4 & 1.0 & 2,010 & 3.9 \\
\hline
\end{tabular}

'Site upstream from Rio Conchos and subreach A. 



\section{Appendix 1. Oxygen and nitrogen isotope data in water-quality samples from the main-stem Rio Grande, Big Bend area, United States and Mexico, February 5-June 29, 2006}


Appendix 1. Oxygen and nitrogen isotope data in water-quality samples from the main-stem Rio Grande, Big Bend area, United States and Mexico, February 5-June 29, 2006.

$\left[0^{18}\right.$, oxygen-18; $\mathrm{O}^{16}$, oxygen-16; $\delta$, delta; ${ }^{15} \mathrm{~N}$, nitrogen-15; --, not analyzed for or not calculated; BBNP, Big Bend National Park $]$

\begin{tabular}{|c|c|c|c|c|c|c|c|}
\hline $\begin{array}{c}\text { Site } \\
\text { number } \\
\text { (fig. 2; } \\
\text { table 1) }\end{array}$ & $\begin{array}{l}\text { Sub- } \\
\text { reach } \\
\text { (fig. 2) }\end{array}$ & Site name & Date & $\begin{array}{c}\text { Deuterium/ } \\
\text { protium } \\
\text { ratio, } \\
\text { water, } \\
\text { unfiltered } \\
\text { (per mil) }\end{array}$ & $\begin{array}{c}\mathbf{0}^{18 / \mathbf{0}^{16}} \\
\text { ratio, } \\
\text { water, } \\
\text { unfiltered } \\
\text { (per mil) }\end{array}$ & $\begin{array}{c}\delta^{18} 0, \\
\text { water, } \\
\text { filtered } \\
\text { (per mil) }\end{array}$ & $\begin{array}{c}\delta^{15} \mathrm{~N}, \\
\text { water, } \\
\text { filtered } \\
\text { (per mil) }\end{array}$ \\
\hline 1 & $\mathrm{U}^{1}$ & Rio Grande above Rio Conchos near Presidio, Tex. & $6 / 29 / 2006$ & -- & -- & -- & -- \\
\hline 2 & A & Rio Grande below Rio Conchos near Presidio, Tex. & $6 / 29 / 2006$ & -- & -- & -- & -- \\
\hline 3 & A & Rio Grande at Rancherias Rapids near Redford, Tex. & $6 / 20 / 2006$ & -31.9 & -2.82 & 4.03 & 9.75 \\
\hline 4 & A & Rio Grande above Lajitas, Tex. & $6 / 20 / 2006$ & -24.6 & -1.02 & -- & -- \\
\hline 5 & B & Rio Grande at Santa Elena Canyon, BBNP, Tex. & $2 / 6 / 2006$ & -47.7 & -5.42 & -- & -- \\
\hline 6 & B & Rio Grande near Castolon, BBNP, Tex. & 2/6/2006 & -49.0 & -5.37 & -- & -- \\
\hline 7 & B & Rio Grande at Johnson Ranch near Castolon, Tex. & 2/7/2006 & -48.0 & -5.30 & -- & -- \\
\hline 8 & B & Rio Grande at Talley Campground, BBNP, Tex. & $2 / 8 / 2006$ & -45.9 & -5.00 & -- & -- \\
\hline 10 & B & Rio Grande at La Clocha Campground, BBNP, Tex. & 2/9/2006 & -45.6 & -5.03 & -- & -- \\
\hline 13 & B & Rio Grande at Rio Grande Village, Tex. & 2/9/2006 & -46.3 & -5.44 & -- & -- \\
\hline 15 & $\mathrm{C}$ & Rio Grande at La Linda, Mexico & $6 / 22 / 2006$ & -36.7 & -4.32 & -- & -- \\
\hline 17 & $\mathrm{D}$ & Rio Grande at Taylor's Farm near Sanderson, Tex. & $3 / 13 / 2006$ & -43.7 & -5.32 & 4.77 & 9.07 \\
\hline 20 & $\mathrm{D}$ & Rio Grande above Silber Canyon near Sanderson, Tex. & $3 / 15 / 2006$ & -44.3 & -5.54 & 6.61 & 10.30 \\
\hline 24 & $\mathrm{D}$ & Rio Grande below Rodeo Rapids near Sanderson, Tex. & $3 / 16 / 2006$ & -45.3 & -5.90 & 6.96 & 9.38 \\
\hline 26 & $\mathrm{D}$ & Rio Grande below Panther Gulch near Sanderson, Tex. & $3 / 18 / 2006$ & -44.8 & -5.84 & 5.93 & 8.78 \\
\hline 29 & $\mathrm{E}$ & Rio Grande above Shafter Crossing near Dryden, Tex. & 2/5/2006 & -47.1 & -6.05 & 5.68 & 8.79 \\
\hline 32 & E & Rio Grande above Lozier Canyon near Dryden, Tex. & $2 / 8 / 2006$ & -45.6 & -6.09 & 4.57 & 8.58 \\
\hline 34 & $\mathrm{E}$ & Rio Grande at Foster Ranch near Langtry, Tex. & $2 / 8 / 2006$ & -- & -- & -- & -- \\
\hline 36 & $\mathrm{E}$ & Rio Grande above Rattlesnake Canyon near Langtry, Tex. & $2 / 10 / 2006$ & -44.3 & -5.98 & 4.47 & 8.33 \\
\hline 38 & $\mathrm{E}$ & Rio Grande at take-out near Langtry, Tex. & 2/11/2006 & -44.3 & -6.01 & 4.81 & 8.66 \\
\hline
\end{tabular}

${ }^{1}$ Site upstream from Rio Conchos and subreach A.

Publishing support provided by

Lafayette Publishing Service Center

Information regarding water resources in Texas is available at

http://tx.usgs.gov/ 

V

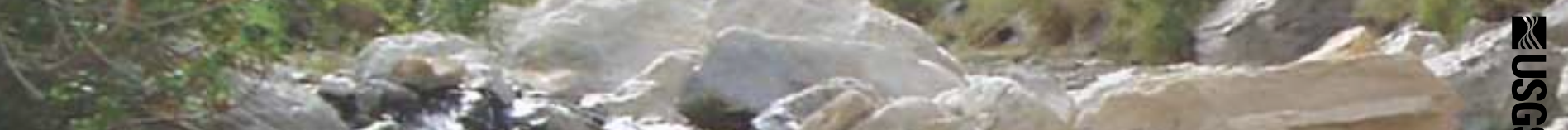

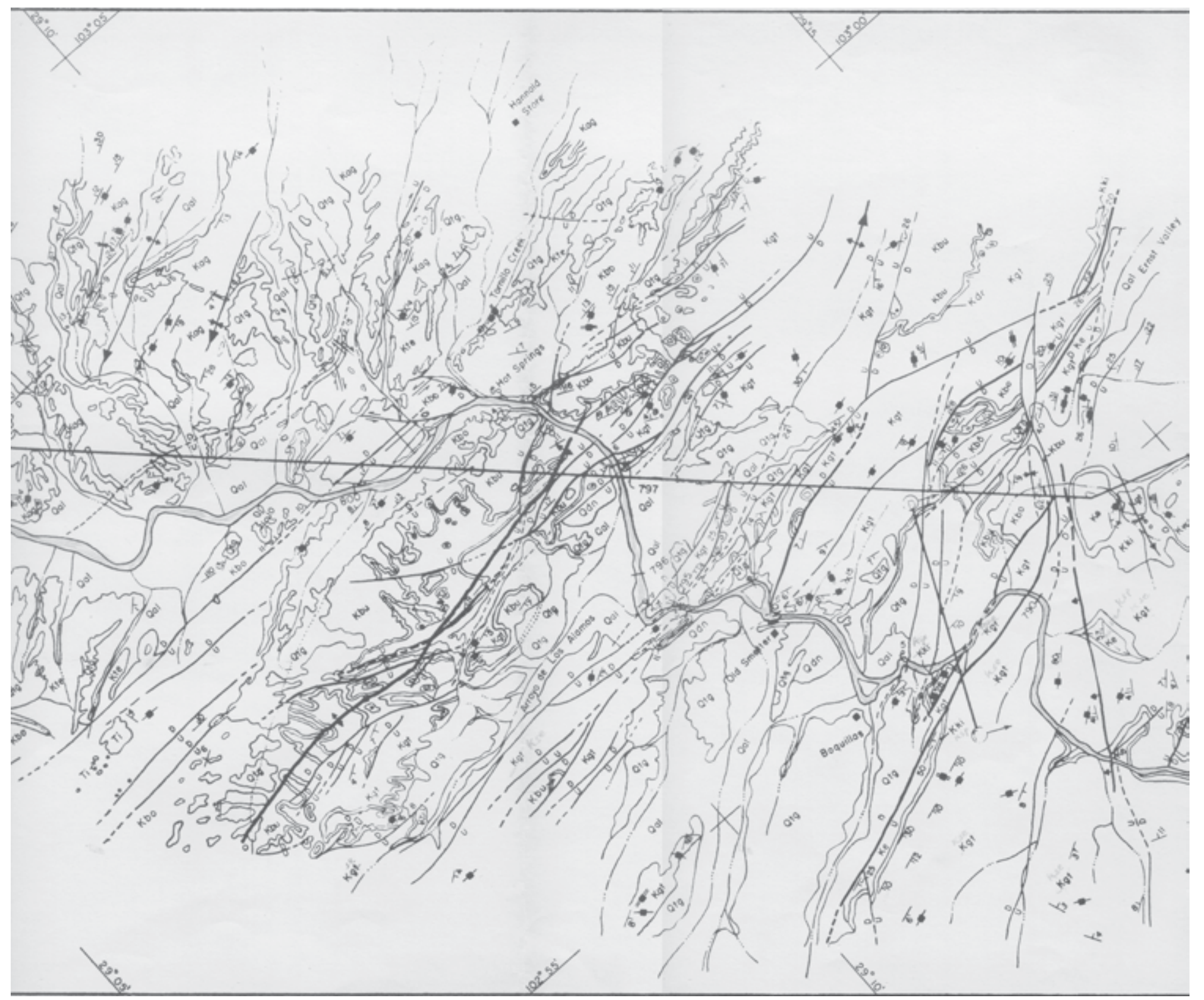

공

긍

음

음

-

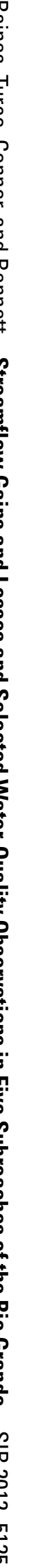

